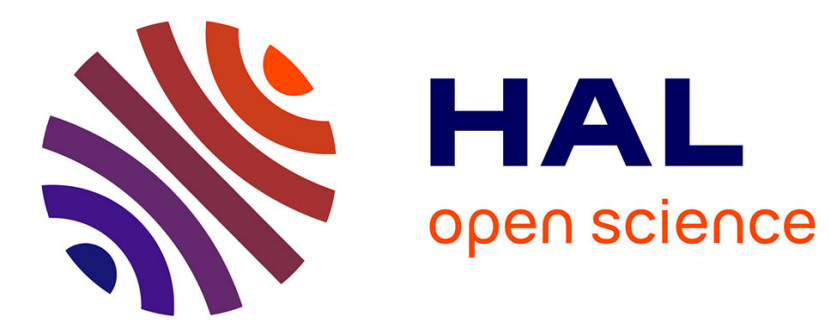

\title{
Multispecies Impingement in a Tropical Power Plant, Straits of Malacca
}

\author{
A. Azila, V.C. Chong
}

\section{To cite this version:}

A. Azila, V.C. Chong. Multispecies Impingement in a Tropical Power Plant, Straits of Malacca. Marine Environmental Research, 2010, 70 (1), pp.13. 10.1016/j.marenvres.2010.02.004 . hal-00598201

\section{HAL Id: hal-00598201 \\ https://hal.science/hal-00598201}

Submitted on 5 Jun 2011

HAL is a multi-disciplinary open access archive for the deposit and dissemination of scientific research documents, whether they are published or not. The documents may come from teaching and research institutions in France or abroad, or from public or private research centers.
L'archive ouverte pluridisciplinaire HAL, est destinée au dépôt et à la diffusion de documents scientifiques de niveau recherche, publiés ou non, émanant des établissements d'enseignement et de recherche français ou étrangers, des laboratoires publics ou privés. 


\section{Accepted Manuscript}

Title: Multispecies Impingement in a Tropical Power Plant, Straits of Malacca

Authors: A. Azila, V.C. Chong

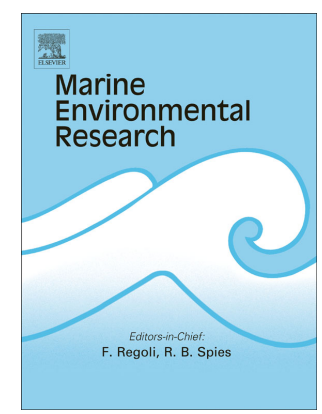

PII:

S0141-1136(10)00038-3

DOI:

10.1016/j.marenvres.2010.02.004

Reference:

MERE 3425

To appear in: Marine Environmental Research

Received Date: 17 July 2009

Revised Date: 11 February 2010

Accepted Date: 18 February 2010

Please cite this article as: Azila, A., Chong, V.C. Multispecies Impingement in a Tropical Power Plant, Straits of Malacca, Marine Environmental Research (2010), doi: 10.1016/j.marenvres.2010.02.004

This is a PDF file of an unedited manuscript that has been accepted for publication. As a service to our customers we are providing this early version of the manuscript. The manuscript will undergo copyediting, typesetting, and review of the resulting proof before it is published in its final form. Please note that during the production process errors may be discovered which could affect the content, and all legal disclaimers that apply to the journal pertain. 


\section{A. Azila ${ }^{\mathrm{a}}$, V.C. Chong ${ }^{\mathrm{a}, \mathrm{b}, *}$}

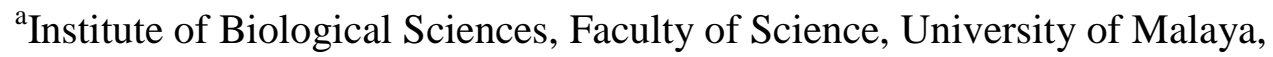

${ }^{\mathrm{b}}$ Institute of Ocean \& Earth Sciences, University of Malaya

50603 Kuala Lumpur, Malaysia

*corresponding author: Tel.:603-79674220; fax: 603-79674178.

E-mail address: chong@um.edu.my

\footnotetext{
Abstract

Marine organisms comprised about $70 \%$ of the total impinged materials by weight at water intake screens in the Kapar Power Station (KPS), Malaysia. The general groupings of 'fish', 'shrimp', ‘crab', 'cephalopod' and 'others' contributed 26\%(87 species), 65\%(29), 2\%(17), 2\%(3) and 5\%(42) of the total number of impinged organisms, respectively. In general, higher impingement occurred during spring tide, at nighttime and in shallow water. The glass perchlet, anchovies, ponyfishes, mojarra, catfishes, hairtail, scat and young croakers were the most vulnerable fishes. Vulnerable invertebrates included cephalopods, sea urchin, rockshells and jellyfishes, but penaeid shrimps were the most susceptible in terms of both mortality and body injury. Annually, KPS is estimated to kill $8.5 \times 10^{6}$ marine organisms (42 tons) by impingement. This amount, however, is minimal compared to commercial fishery harvests. Multispecies impingement at Malaysian power plants poses the problem of finding the best mitigation options for tropical situations.
} 
Multispecies impingement; Diel and tidal effects; Impacts

\section{Introduction}

Once-through cooled (OTC) power plants extract massive quantities of seawater to cool down superheated steam in their condensers. A single large power plant can extract millions of cubic meters of cooling water daily before discharging much of that water back into the sea at temperatures much higher than before. Withdrawn seawater, debris, fish and other organisms are forcibly impinged against filter screens installed to prevent debris from entering the cooling system which could cause serious damage to equipment and even shut down of the power plant (Majewski and Miller, 1979; Ronafalvy et al., 2000). Fish striking or caught on the screen surface however suffer injury, asphyxiation or mortality. The fish impingement process is also influenced by environmental conditions and fish behavior, besides the plant operation. In contrast to impingement, entrainment is the process whereby fish eggs, larvae and small fishes of usually less than 50mm length pass through the screens but are trapped and killed off by high temperature and chlorine inside the cooling system (Vaughan, 1988; Turnpenny and Taylor, 2000).

Fish mortality induced by both impingement and entrainment has been the main environmental issue involving power plants. While entrainment mortality is usually very high, for instance, 132 million fish eggs and larvae or $23 \%$ of the total river ichthyoplankton at Wabash River Station, USA, clear adverse impacts on fish populations have been difficult to quantify (Lewis and Seegert, 2000). Impingement mortality although very variable may be in the order of tens of millions of fish annually (Hadderingh and Jagger, 2002; Greenwood, 2007). In the UK, impinged fish losses at east coast power stations ranged from $0.22 \%$ of the commercial catches for cod to $180 \%$ for whiting (Turnpenny and Taylor, 2000). In contrast, 15 harvested fish stocks off the California and Atlantic coasts were estimated to be depressed by entrainment and impingement by less than $1 \%$ in 10 of 15 cases considered, between 1-3\% in two cases, and between $20-80 \%$ in three cases (Newbold and 
to the extracted volume of cooling water (Henderson and Seaby, 2000; Greenwood, 2007). Based on an estimated $50-75 \%$ total pumping capacity used annually by 45 large power stations in north European waters, Henderson (2009) estimated a total of 3-5 x $10^{8}$ fish and about $10^{14}$ fish eggs and larvae killed annually by impingement and entrainment.

There are seven coastal OTC power plants in Malaysia, which were built relatively recently to cater for the country's increasing demand for electricity. Environmental impacts of the siting and operation of these power plants are unknown, but concern of high impingement and entrainment mortality of marine organisms is not without basis since several of these electric power plants are sited on or close to mangroves or tidal flats known to serve as nursery areas for marine fauna (Chong, 2007). New power plants, including nuclear power, are being planned for the future to cater for the country's fast growing population and economy. In fact, the proliferation of power plants in the ASEAN region is imminent in the near future based on the International Energy Agency (IEA)'s 2009 World Energy Outlook forecast stating that the energy demand of the ten ASEAN countries would expand by $76 \%$ for the period $2007-2030$.

Given the lack of knowledge on power plant impacts in tropical waters, the aim of this study was to determine the biotic losses due to impingement at cooling water intakes in the Kapar Power Station (Malaysia), which is located at a coastal mudflat near to mangrove forests. This OTC power station extracts up to 6 million $\mathrm{m}^{3}$ of sea water daily.

\section{Material and methods}

\subsection{Study sites}

Kapar Power Station (hereafter referred to as KPS) is a coal-, oil- and gas-fired thermal electricity generating station facing the Straits of Malacca. KPS (Lat $3^{\circ} 06^{\prime} 47.02{ }^{\prime} \mathrm{N}$, Long $101^{\circ}$ 19’06.89’E) is located $24 \mathrm{~km}$ north of Port Klang, Malaysia’s largest port (Fig. 1). The power 
mudflat fronts the station to as far as a kilometer offshore, while mangrove forests (and mudflats)

line the upper shore to the north and south of it. Much of the mangrove forests are however converted for agriculture and industrial development leaving only a narrow coastal strip of $0.5-1 \mathrm{~km}$ width. The study area experiences strong semidiurnal tides, and sea level rises and falls within a mean range of $4.2 \mathrm{~m}$ and $1.4 \mathrm{~m}$ with tidal velocities reaching $1.5 \mathrm{~ms}^{-1}$ and $0.4 \mathrm{~ms}^{-1}$ for spring and neap tide, respectively (Chong et al., 1996).

The power station currently generates $2420 \mathrm{MW}$ of electricity to help support the power demand of the nation's most populated region, the Klang Valley. KPS has been operating since 1987 when it first started with two intake points for cooling water extraction (Phase I), followed by two additional intake points at its second phase of operation, and finally in 1991 two further intake points were added (Phase III). The six intake points have a combined water extraction rate of $71.4 \mathrm{~m}^{3} \mathrm{~s}^{-1}$

The circulating water system used at KPS is an open system, whereby seawater enters the circulating water pump (CWP) bays through an intake structure. Primary screens (vertical bar screens) prevent large debris from entering the CWP bays, furthermore any debris that passes through them is blocked by a rotary drum screen. Debris such as fish, leaves, garbage, etc. caught on the drum screen (10-mm mesh) are washed down by high pressure seawater jets, before flowing down along steel chutes and finally into steel trash baskets.

The heated once-through cooling water is returned via two discharge outlets, one at the southern end of the station and the other at its northern end. Measurements taken along a $4 \mathrm{~km}$-transect from the south outfall towards sea recorded water temperatures of $32-29^{\circ} \mathrm{C}$ and salinities of $22-28 \mathrm{ppt}$, although thermal plumes moving up the narrow Kapar estuary during flood tide could yield temperatures of up to $36^{\circ} \mathrm{C}$ (Anton, 1990). The heat however quickly dissipates beyond $0.5 \mathrm{~km}$ from the outfall.

Unit 1 (Phase I) and Unit 6 (Phase III) of the intake points at KPS were chosen as the sampling locations for impinged marine organisms. Due to siltation, Unit 1, located approximately $0.75 \mathrm{~km}$ 
average water depth is now less than $5 \mathrm{~m}$, whereas originally it was $7 \mathrm{~m}$. Unit 6 is located another

$0.44 \mathrm{~km}$ farther out into deeper water.

\subsection{Sampling design}

The tidal height at the study site was determined from the local Tide Table (Royal Malaysian Navy, 2004) from May 26 through to July 19, 2004, to choose the appropriate sampling time. Fish and invertebrates were sampled from the steel trash basket of each intake unit at approximately12hourly sampling intervals for two consecutive days (thus, two-day and two-night samples) each week. The exact sampling times ranged from 9.7 to 12.8 hours. Samples were collected for four consecutive weeks covering $1^{\text {st }}$ quarter, full moon, $3^{\text {rd }}$ quarter and new moon phases. Due to the station's administrative constraints, samplings at Unit 6 were carried out one month after sampling Unit 1.

For standardization purpose, the 12-hour period from $0800 \mathrm{hr}$ to $2000 \mathrm{hr}$ was designated as “day" sampling and from $2000 \mathrm{hr}$ to $0800 \mathrm{hr}$ the next morning was designated as "night" sampling.

The entire sample contained a mix of marine organisms and solid wastes. Organisms and inert debris were separated and weighed on site. The latter was recorded qualitatively before discarding. Collected organisms were taken either entirely or subsampled (50\%) if the quantity was large. The samples were then preserved in $10 \%$ formaldehyde in large plastic bins and taken back to the laboratory for further examination.

\subsection{Laboratory analysis}

In the laboratory, samples preserved for at least a week were first washed in running water for several hours before they were transferred into $70 \%$ alcohol prior to examination. Samples were sorted and identified to species level whenever possible using available taxonomic keys. After 
particular date and time were recorded. Qualitative assessment of body condition of the specimens in term of damage condition was also noted.

\subsection{Data analysis}

Due to the many and varied types of marine organisms obtained, they were grouped into five general faunal categories: 'fish', 'shrimp', 'crab', 'cephalopod' and 'others'. Shrimp comprised decapod and mantis shrimps. Data on the abundance and biomass of species impinged were calculated in terms of catch per unit effort (CPUE), i.e. number and weight of individuals per 12 hour-sampling.

Two-way analysis of variance (ANOVA) was performed using the STATISTICA software on $\log _{10^{-}}$transformed CPUE of each faunal category. The factors tested were tide (NM- new moon, Q1- $1^{\text {st }}$ quarter, FM- full moon, Q3- $3^{\text {rd }}$ quarter) and diel effect (day, night).

\section{Results}

\subsection{Proportion of impinged living organisms}

During the screening process, not only marine organisms were separated out of the intake cooling water, but also inert materials or solid debris such as leaves, twigs and propagules, empty mollusc shells, plastic bags and bottles, rag fabrics, fish nettings and other garbage. The proportion of marine organisms to inert materials collected at Unit 1 and Unit 6 was quite similar, with an average ratio of about 2:1. The entire collection of marine organisms at Unit 1 (16 12-hr sampling periods) totaled 43,845 specimens weighing $156.67 \mathrm{~kg}$, whereas for the deeper water Unit 6 (16 12- 
( \pm 10.6$)$, and at Unit 6 these were $1145( \pm 610)$ and $9.4 \mathrm{~kg}( \pm 7.8)$.

The proportion (\%) of marine organisms to inert materials collected during nighttime was 72.34: 27.66 by weight as compared to $62.45: 37.55$ during day. CPUE of total impinged marine organisms at night (mean=3864) was always higher than day $(1617)(\mathrm{P}=0.003)$, with a mean ratio of night to day impingement of $3.1( \pm 1.8)$ at Unit 1 . At the deeper water Unit 6 , night (1205) and day (1086) CPUE were about equal with no significant difference $(\mathrm{P}=0.60)$; mean ratio of night to day impingement was $1.35 \pm 0.93$.

In term of total impingement by weight $(\mathrm{kg} / 12 \mathrm{hr})$, the results were similar as with CPUE (numbers); 13.18 and 6.41 for Unit 1 and 8.05 and 10.72 for Unit 6, during night and day respectively. Mean weight ratio of night to day impingement was $3.29( \pm 3.15)$ and $1.13( \pm 0.66)$ for Unit 1 and 6, respectively. The rate of impingement of inert material appeared to be similar during night and day at Unit 1, but at Unit 6 the inert material collected during night was half as much as during day.

The proportion of inert material to marine organisms however increased from neap to spring tide reflecting the stronger tidal currents during spring tide that moved the inert materials into the water intakes. At the same time, impingement of marine organisms significantly increased during spring tide $(\mathrm{P}<0.05)$. At Unit 1 , the mean total impinged organisms ranked and statistically tested (5\% significance level) for moon phase are as follows: FM (7138) > NM (2662) > Q1 (628) $\approx$ Q3 (534). At Unit 6, these were FM $(1873) \approx$ Q3 $(1031) \approx \mathrm{NM}(1020) \approx \mathrm{Q} 1(658)$; only FM was significantly greater than $\mathrm{Q} 1(\mathrm{P}<0.05)$.

\subsection{Species of impinged marine organisms}

Appendix A lists the 178 species of marine organisms impinged on the water intake screens of KPS during the study. 114 species are listed as economically important species contributing to $90 \%$ 
marine organisms comprised 87 species of fishes, 22 species of decapod shrimps, 7 species of stomatopods (mantis shrimps), 17 species of crabs, 3 species of cephalopods, and 42 species of other organisms comprising scyphozoan jellyfish (5), polychaetes (6), gastropods (6), bivalves (3), horse-shoe crabs (2), anomurans (3), isopods (1), sea urchins (1), sea cucumbers (14) and brittle star (1).

Anchovies (Thryssa kammalensis, Coilia dussumieri), croaker (Dendrophyssa russelii), ponyfishes (Leiognathus splendens, Secutor insidiator), mojarra (Gerres erythrourus), catfishes (Arius sagor, A. maculatus), hairtail (Lepturacanthus savala) and scat (Scatophagus argus) were among the most frequently impinged fish (> 80\% occurrence). Among invertebrates, penaeid shrimps (Penaeus merguiensis, Metapenaeus spp., Parapenaeopsis spp.), small swimming crabs (Charybdis spp.), the leaf porter crab (Neodorippe callida), sea urchin (Salmacis dussumieri) and the spineless cuttlefish (Sepiella inermis) were the most frequently impinged. Rockshells (Thais spp.), which are common predators of mudflat bivalves, were also frequently impinged (91\%). The large but slow-moving bottom dweller of the mudflat, the horse-shoe crab (Carcinoscopius rotundicauda), appeared quite vulnerable to impingement (72\%).

From the total of 62,169 individuals of impinged marine organisms, the percentage compositions of the different groups of marine organisms are as follows: fish (26\%), shrimp (65\%), crab (2\%), cephalopod (2\%) and others (5\%). Based on abundance, the two highest impinged species were the penaeid shrimp, Metapenaeus affinis, and the glass perchlet, Ambassis gynmocephalus. Two other penaeid shrimps ranked third (Penaeus merguiensis) and fourth (M. brevicornis) highest. The top 20 species comprised seven decapod shrimps, eight fishes, two cephalopods, one sea urchin, one gastropod and one edible jellyfish (Lobonema smithii). All had impingement frequency exceeding 66\% except the latter (19\%) indicating the infrequent but large swarms of jellyfish when present.

\subsection{Species richness}




\subsection{Vulnerability in relation to diel and tidal changes}

Fishes, shrimps and cephalopods showed higher impingement rates during night than day $(\mathrm{P}<0.05)$. Fish and shrimps in particular were also more heavily impinged during spring tide than neap tide, especially during full moon $(\mathrm{P}<0.05)$ (Fig. 3). Most of the fish species that were impinged at higher numbers during spring tide and nighttime were croakers (e.g. Johnius belangerii, Johnius borneensis, Dendrophyssa russelii, Nibea soldado and sciaenid juveniles), catfishes (e.g. Arius sagor and Arius maculatus) and the scat (Scatophagus argus). However, a few species such as white pomfret (Pampus argenteus), anchovy (Thryssa hamiltonii), carangid (Alepes djeddaba) and ponyfish (Leiognathus splendens) were more impinged during night neap tides.

Shrimps that were more susceptible to impingement at night during spring tide included Parapenaeopsis sculptilis, Metapenaeus ensis, Penaeus merguiensis and Palaemon styliferus. However, stomatopods were more impinged during spring tide with no diel effect. Small and weaker shrimps such as sergestid (Acetes sp.), hippolytid (Mimocaris sp.) and postlarvae of stomatopods were equally vulnerable during both spring and neap tides.

Crabs that were more impinged during spring tide were mainly swimming crabs such as Portunus pelagicus and Charybdis japonica. In contrast, species such as Hyastenus diacanthus and Myomenippe hardwickii appeared vulnerable during daytime irrespective of tidal conditions. The spineless cuttlefish, Sepiella inermis, tended to be more impinged at night irrespective of tide, while an octopus (Octopus sp.) was subject to higher impingement during spring tide with no diel effect. 
(23\%), crab (2\%), cephalopod (6\%) and others (29\%). In term of biomass, the highest was the catfish A. sagor, followed by the edible jellyfish (Lobonema smithii), the horse-shoe crab (T. gigas), the scat and spineless cuttlefish. In contrast to abundance, none of the biomass of shrimp species was ranked in the top five. Fish, shrimps and cephalopods also showed higher impinged biomass during night than day. Impingement rates were also higher during spring tide (particularly full moon) for fish and shrimps (Table 1).

\subsection{Size of Impinged Marine Organisms}

The average sizes of fish, shrimp, crab and cephalopod were $7.51 \mathrm{~g}, 1.77 \mathrm{~g}, 5.04 \mathrm{~g}$ and $14.83 \mathrm{~g}$, respectively (see Table 1). Thus, the majority of impinged organisms were small juveniles.

\subsection{Assessment of injury caused by impingement}

Among the five broad categories, shrimps suffered the highest injury by weight (Fig. 4), with damaged ones constituting $56 \%$ of the total shrimp biomass. Visible injuries consisted of crushed carapace and exoskeleton, eye injury and broken appendages. Crabs suffered lower damage (16\%) as did cephalopods $(0.2 \%)$. Some $98 \%$ of impinged fish had little signs of external body damage. Observed injuries were in the form of damaged fins and skin, scale loss and bruised bodies.

Jellyfish (scyphozoan medusa) were the most damaged amongst the 'Others' category, suffering about $17 \%$ damage due to broken body parts.

\subsection{Estimated annual loss by impingement}

In this study, $100 \%$ mortality is assumed for all impinged marine organisms, as there is no recovery system installed at KPS. Estimation of annual impingement was made based on the assumption of worst-case scenario, that is, cooling water was continuously extracted at all six water 
organisms at KPS based on our study of 32 consecutive biweekly samplings over two months at all

\section{Discussion}

The estimated annual fish impingement of $2.2 \times 10^{6}$ (16.54 tons) at KPS is lower than power stations of comparable size, for example, at the 2400 MW Longannet Power Station on the Forth estuary, UK, where $1.25 \times 10^{7}$ (74 tons) and $4.41 \times 10^{7}$ fish (184.4 tons) were impinged in 1999 and 2000 respectively (Greenwood, 2008), but closer to the Pembroke power station at Daugleddau estuary, UK, where an estimated $1.6 \times 10^{6}$ fish were impinged (Turnpenny et al., 1997). The Malaysian estimate also falls within the fish impingement mortality of $79 \times 10^{3}-9.6 \times 10^{6}(13-$ 18.6 tons) reported at Calvert Cliffs Nuclear Power Plant, USA (Ringger, 2000). However, fish impingement mortality at power stations varies markedly, seasonally and annually (Table 3), being affected by such factors as fish aggregation, latitude, habitat, tidal action and intake flow (see Hocutt et al., 1980; Henderson, 1989; Greenwood, 2007).

It is not known how density-dependent (or density-independent) mortality operates and thus modifies fish impingement, but competing impingement caused by other marine biota may be important. Impingement in tropical waters may be characteristically species-rich as in KPS where 178 species of marine biota were recorded over a 2-month period. In fact, a major portion of the estimated total biota impinged on KPS screens $\left(8.5 \times 10^{6}\right)$ consisted of invertebrates. Impinged fish species, which totaled 87 species, represent $43.5 \%$ of the 200 recorded fish species in Klang Strait (Chong et al., 2005). The total (cumulative) number of impinged fish species recorded in just the first month of study (sixteen 12-hourly samples) was 68. In contrast, impingements of more than 68 fish species in temperate waters are cumulative species number recorded from one to 21 years of study (Table 3). Seven British power stations had mean numbers that ranged from 18.5 - 35 species (Henderson, 1989). In sub-tropical waters, for e.g. Taiwan, the cumulative fish species 
(4 - 48 species) were nearly the same as in KPS for a 12-hour sample.

The maximum species number (MSN) at KPS site is close to 200 species or approximately 100 each for fish and invertebrates (see Fig. 2). This number is larger than the MSN values reported for seven temperate power plant sites that ranged from 51 - 80 fish species (Henderson, 1989), but close to the sub-tropical MSN value of 196 species reported in Taiwan waters (Liao et al., 2004). Henderson (1989) derived an empirical linear relationship $(\mathrm{S}=-7.85 \mathrm{~L}+478.8)$ for species numbers (S) against latitude (L, in degrees) which fitted very well the data from temperate power plants in marine waters (species number also declines with declining salinity), and proposed the rule of a maximum of 80 species that any UK sites may hold. Including the tropical (KPS $=3$ degrees) and sub-tropical (Taiwan $=25$ degrees) MSN values in the analysis may imply a more general parabolic relationship from the northern to southern hemisphere. However, more research in tropical and sub-tropical sites is needed to test this interesting relationship.

Fish impingement in temperate waters also indicates the dominance of a few species. In most cases, two species combined would have contributed more than $60 \%$ of the total number of fish impinged (see Table 3). In KPS, the most abundant species of fish (Ambassis gymnocephalus) and shrimp (Metapenaeus affinis) respectively contributed to only 5\% and $10 \%$ of the total number of impinged organisms. Thus, the lower proportion of fish impinged at KPS screens results from competing impingement due to the high diversity of other marine organisms in tropical waters.

Shrimps are the most susceptible biota at KPS; impingement kills 2.5 times more shrimps (5.55 $\mathrm{x} 10^{6}$ ) than fish. Fourteen of 17 ever-recorded species of penaeid shrimps in Klang Strait (Chong et al., 2005) were amongst those impinged. All three palaemonid shrimp species ever reported in the area were also impinged. The present study also indicates that fish and shrimps are more vulnerable to impingement in shallow water $(<5 \mathrm{~m})$ since Unit 1 had $24 \%$ higher impingement than Unit 6 which is located further offshore ( $>7 \mathrm{~m}$ depth). These results are not unexpected since the juveniles of many marine fishes use Klang mangrove and coastal mudflats as feeding areas, while penaeid shrimps depend on them for nursery areas (Newell et al., 1995; Chong et al., 2005). 
protection from larger predators (Blaber, 2000; Chong, 2007). As the mudflat becomes inundated

with seawater during high spring tide, more feeding or refuge ground becomes available, thus attracting more marine organisms into it and into the adjacent mangrove forest. This would explain why higher numbers of juvenile fishes, shrimps and others were impinged at KPS screens during spring tide. In general, tidal changes have a strong influence on the impingement rate of marine organisms at the cooling water intakes, due to the inability of these organisms to quickly swim away from the combination of strong tidal flow and water suction, although some might just passively drift into them.

Penaeid shrimps, particularly M. brevicorni, M. affinis and Pa. sculptilis, are subject to higher impingement during nighttime. Such species become active at night when in the day they burrow under sediment to avoid predators, a behavior that explains why trawl catches of shrimps were higher during night than day (Low and Chong, 1999; Chong, 2007). Like shrimp, fish vulnerability also depends on behavior, tidal and diel activity as well as their swimming agility (Krumme et al., 2004). Demersal fish species such as young croakers, catfish and scat which feed on small shrimps (Then, 2008) are also more vulnerable during night and spring tide, while weak pelagic swimmers such as pomfret, ponyfish and anchovy are more vulnerable during night and neap tide. It is not clearly understood why, only in shallow water, night impingement was 3 times higher than day impingement, while full moon impingement was $1.8-2.7$ times higher than new moon impingement. In a few other species, there were no apparent effects of light (e.g. octopus, horseshoe crab and stomatopods); higher impingement occurred at night (cuttlefish) or day (some non-swimming crabs) irrespective of tide; and impingement was equal at neap and spring tide (sergestid and hippolytid shrimps). Heavy debris loads such as plastic bags and mangrove leaves could reduce an organism's ability to avoid impingement, as for example, eelgrass or algae that were impinged on traveling screens reportedly entangled other organisms (Duke Energy, 2001). It appears that the severity of impingement in tropical waters is dependent on the interaction effects of environmental factors like tide, light, water depth and inert materials on the one hand, and 
to elucidate these and other factors.

Consistent with the mangrove and mudflat's function as nursery or feeding area, fish, shrimps and most other marine organisms impinged at KPS were predominantly juveniles, which are the most vulnerable and weakest swimmers. This means that the siting of the power plant itself would significantly influence the impingement rate of marine biota. Hence, its location on the mudflat area as well as near to mangroves is deemed not suitable and expected to cause higher impingement as compared to a location farther out into the sea, or away from any of these critical habitats. The estimated total annual impingement at KPS of 42 tons represents only $0.1 \%$ of the annual marine landings of 44,800 tons for the combined districts of Port Klang and Kuala Selangor (Selangor State Fisheries Statistics, 2002). Nevertheless, the impingement mortality applies to young juveniles (see Table 1) and if there was no power plant, the removed organisms could translate into larger harvestable adults. Due to the lack of information on fish population parameters, the present study did not derive an equivalent adult loss (Turnpenny, 1988) or assess population level impacts using age-structured population models (e.g. Newbold and Iovanna, 2007). These types of analysis as conducted in temperate waters indicate that in many cases the equivalent adult losses or impact on fish populations due to impingement at single power plant are generally minimal in comparison to fishery landings or by-catches (Turnpenny and Coughlan, 1992; Turnpenny and Taylor, 2000; Newbold and Iovanna, 2007; Greenwood, 2008), but severe for a few cases (Newbold and Iovanna, 2007). However, the collective effect of several power plants in the same region, as for instance in northern European waters, can be colossal: 17 power stations in the southern North Sea are estimated to kill sole and herring equivalent to about $50 \%$ of Britain's commercial landings for the region (see Henderson, 2009).

The severity of the impingement and entrainment (I\&E) problem is nevertheless strong enough to trigger stringent law enforcement in most temperate countries where power plants are common. Monitoring studies are mandatory and intensively carried out to assess impacts even though mitigation measures are implemented in many power plants. For example, in the USA and UK, 
capacity of intake structures reflect the best available technology for minimizing environmental

impact, which is an attempt to deal with the problems of I\&E. In Malaysia, although the

Environmental Quality Act, 1974, provides for similar considerations in an EIA prior to building

the power plant, I\&E effects are not considered a monitoring requirement. Because of this, the long term impacts of power plants due to I\&E have been largely unknown or ignored. While it may become mandatory for plant managers to institute mitigation measures and monitoring at some point in the future, it is incumbent upon them to do so now, and to fulfill a CSR obligation to protect the environment. The benefits of monitoring are enormous benefiting both industrial and public interests (Henderson et al., 2007). Several studies by Henderson and co-workers (e.g. Henderson, 1989; Henderson et al., 1992) have shown how potentially useful power plant catches can be utilized to advance scientific knowledge on carrying capacity, niche occupation and trophic structure, and in the process, to give good advice pertaining to power plant siting and operations.

In conclusion, this study showed that total organism mortality caused by impingement on water-cooling screens at KPS is substantial, although the juvenile biomass removed by impingement is low in comparison to fisheries landings. In contrast to impingement dominated by a few main fish species in temperate waters, multispecies impingement occurs at KPS with implication on mitigation options. Continuous impingement monitoring at power plants in Malaysia is strongly advised as are further studies on the subject and the entrainment issue, which was not covered in the present study. The I\&E problem is very relevant to the current issue of shrimp stock depletion due to overfishing and loss of nursery habitats whereby the state suffered 47\% mangrove loss from 1980-2000 (Chong, 2006). Impingement further kills 5.5 million juvenile shrimps, while entrainment would remove a portion of the estimated 65 billion shrimp larvae recruited into Klang Strait annually (Chong et al., 1996). The number and siting of future power plants should be critically evaluated; power plants should never be sited near mangrove or on the mudflat where the larvae and juveniles of marine organisms abound all year round. 
We are grateful to the University of Malaya for providing research grant F0219/2004A and facilities to support this research. Thanks to Drs. A. Sasekumar, Peter Ng K.L. and Helen Larson for taxonomic assistance, Dr. Mark Freeman for proof reading the manuscript, and to the two anonymous reviewers for their suggestions and improvements to the manuscript. Thanks to Mr. Abdul Rahman Husin, General Manager of Kapar Power Station, for permitting this study, and to all station and university staff for their cooperation throughout the study.

\section{References}

Anton, A., 1990. Effects of thermal discharge on marine phytoplankton, in: Phang, S.M., Sasekumar, A., Vikinewswary, S. (Eds.), Proceedings of $12^{\text {th }}$ Seminar Annual Seminar on Research Priorities for Marine Sciences in the 90's, 18 November, 1989, Institute of Advanced Studies, University of Malaya, Kuala Lumpur, pp. 57-64.

Blaber, S.J.M., 2000. Tropical Estuarine Fishes: Ecology, Exploitation and Conservation. Blackwell Science, Australia.

Chong V.C., 2006. Sustainable utilization and management of mangrove ecosystems of Malaysia. Aquatic Ecosystem Health and Management 9(2), 249-260.

Chong V.C., 2007. Mangroves-fisheries linkages - the Malaysian perspective. Bulletin of Marine Science 80(3), 755-772.

Chong, V.C., Sasekumar, A., Wolanski, E., 1996. The role of mangrove in retaining penaeid prawn larvae in Klang Strait, Malaysia. Mangrove and Salt Marshes 1, 11-22.

Chong, V.C., Sasekumar, A., Zgozi, S., 2005. Fish and prawn communities, in: Sasekumar, A., Chong, V.C. (Eds.), Ecology of Klang Strait. University of Malaya Press, Kuala Lumpur, Malaysia, pp. 179-206.

Duke Energy, 2001. Impingement study. http://www.morro-bay.ca.us/mbpp2.pdf. 
Britain's largest direct-cooled power station. Marine Pollution Bulletin 56, 723-739.

Hadderingh, D.G., Jager, Z., 2002. Comparison of fish impingement by a thermal power plant station with fish populations in the Ems estuary. Journal of Fish Biology 61, 105-124.

Henderson, P.A., 1989. On the structure of the inshore fish community of England and Wales. Journal of Marine Biology Association United Kingdom 69, 145-163.

Henderson, P.A., 2009. Are power stations affecting Northern European inshore fish populations?

In Clients \& Projects - Effects of coastal power stations. (Downloaded from:

http://www.irhouse.demon.co.uk/index.html?2-paper001 ).

Henderson, P.A., Seaby, R.M.H., 2000. Technical Evaluation of US Environmental Protection Agency Proposed Cooling Water Intake Regulations for New Facilities. Pisces Conservation Ltd., Lyminton, UK.

Henderson, P.A., James, D., Holmes, R.H.A., 1992. Trophic structure within the Bristol Channel: seasonality and stability in Bridgwater Bay. Journal of Marine Biology Association United Kingdom 72, 675-690.

Henderson, P.A., Seaby, R.M.H., Somes, R., 2007. Fish and crustacean captures at Hinkley Point B nuclear power station: Report for the year 2006 to March 2007. Pisces Conservation Ltd., Lyminton, UK.

Hocutt, C.H., Stauffer Jr., J.R., Edinger, J.E., Hall Jr., L.W., Morgan II, R.P., (eds), 1980. Power Plants Effects on Fish and Shellfish Behavior. Academic Press, New York.

Krumme, U., Saint-Paul, U. and Rosenthal, H., 2004. Tidal and diel changes in the structure of a nekton assemblage in small intertidal mangrove creeks in northern Brazil. Aquatic Living Resources 17, 215-229

LaJeone, L.L., Monzingo, R.G., 2000. 316(b) and Quad Cities Station, Commonwealth Edison Company. Environmental Science and Policy 3, S313-S322.

Lewis, R.B., Seegert, G., 2000. Entrainment and impingement studies at two power plants on the Wabash River in Indiana. Environmental Science and Policy 3, S303-S312 
Matang mangrove river, in: Kiso, K., Chee, P.S (Eds.), Proceedings of $4{ }^{\text {th }}$ Seminar on

Productivity and Sustainable Utilization of Brackish Water Mangrove Ecosystems, December, 1999, Penang, Malaysia. Japan International Research Center for Agricultural Sciences, Tsukuba, Japan, pp. 89-101.

Majewski, W., Miller, D.C., 1979. Predicting Effects of Power Plant Once-through Cooling on Aquatic Systems. UNESCO, France.

Michaud, D.T., 2000. Wisconsin electric's experience with fish impingement and entrainment studies. Environmental Science and Policy 3, S333-S340

Newbold, S.C., Iovanna, R., 2007. Population level impacts of cooling water withdrawals on harvested fish stocks. Environmental Science and Technology 41, 2108-2114.

Newell, R.I.E., Marshall, N., Sasekumar, A., Chong, V.C., 1995. Relative importance of benthic microalgae, phytoplankton and mangrove as sources of nutrition for penaeid prawns and other coastal invertebrates from Malaysia. Marine Biology 123, 595-606

Reuter, J.M., 1978. Fish impingement at the Davies-Besse nuclear power station during 1977. Environmental Technical Specifications, Sec. 3.1.2.a.6 Fish Impingement, Clear Technical Report No. 83, Toledo Edison Company, Ohio.

Ringger, T.G., 2000. Investigations of impingement of aquatic organisms at the Calvert Cliffs Nuclear Power Plant, 1975-1995. Environmental Science and Policy 3, S261-S273.

Richkus, W.A., McLean, R., 2000. Historical overview of the efficacy of two decades of power plant fisheries impact assessment activities in Chesapeake Bay. Environmental Science and Policy 3, S283-S293.

Ronafalvy, J.P., Cheesman, R.R., Matejek, W.M., 2000. Circulating water traveling screen modifications to improve impinged fish survival and debris handling at Salem Generating Station. Environmental Science and Policy 3, S377-S382.

Royal Malaysian Navy, 2004. Tide Tables of Malaysia and Singapore, Vol.1. Hydrographic Branch, Ministry of Defence, Kuala Lumpur, Malaysia. 
Spicer, G., O’Shea, T., Piehler, G., 2000. Entrainment, impingement and BTA evaluation for an intake located on a cooling water reservoir in the southwest. Environmental Science and Policy 3, S323-S331.

Then, A.Y.H., 2008. The structure and trophodynamics of the Fish Community in Estuaries of Matang Mangrove Forest Reserve, Peninsular Malaysia. MSc Dissertation, Faculty of Science, University of Malaya, Malaysia. Unpublished.

Turnpenny, A.W.H., 1988. Fish impingement at estuarine power stations and its significance to commercial fishing. Journal of Fish Biology 33 (supplement A), 103-110.

Turnpenny, A.W.H. , Coughlan, J., 1992. Power generation on the british coast: thirty years of marine biological research. Hydroécologie appliqué 4, 1-11.

Turnpenny, A.W.H, Taylor, C.J.L., 2000. An assessment of the effect of the Sizewell power stations on fish populations. Hydroécologie appliqué 12, 87-134.

Turnpenny, A.W.H., Coughlan, J., Blay, S.R., Somes, R., 1997. Survey of fish impingement and entrainment, Pembroke Power Station, January-February 1997. Fawley Aquatic Research Laboratories Report. FCR 233/97. (downloaded from www.mfa.gov.uk/ environment/ works/ documents/ statements/ Pembroke/Appendices/AI.6.6.pdf)

Vaughan, D.S. (1988). Entrainment and impingement impacts. In: Barnthouse, L.W, Klauda, R.J., Vaughan, D.S., Kendall, R.L. (Eds.), Science, Law and Hudson River Power Plants. American Fisheries Society Monograph 4, Bethesda, pp. 121-123. 
Table 1.

Total weight and size of impinged organisms by faunal group sampled at 12-hourly intervals following moon phases and diel cycle,

Kapar Power Station, Malaysia. Q1=first quarter, FM=full moon, Q3=third quarter, NM=new moon; D=day time, N=night time.

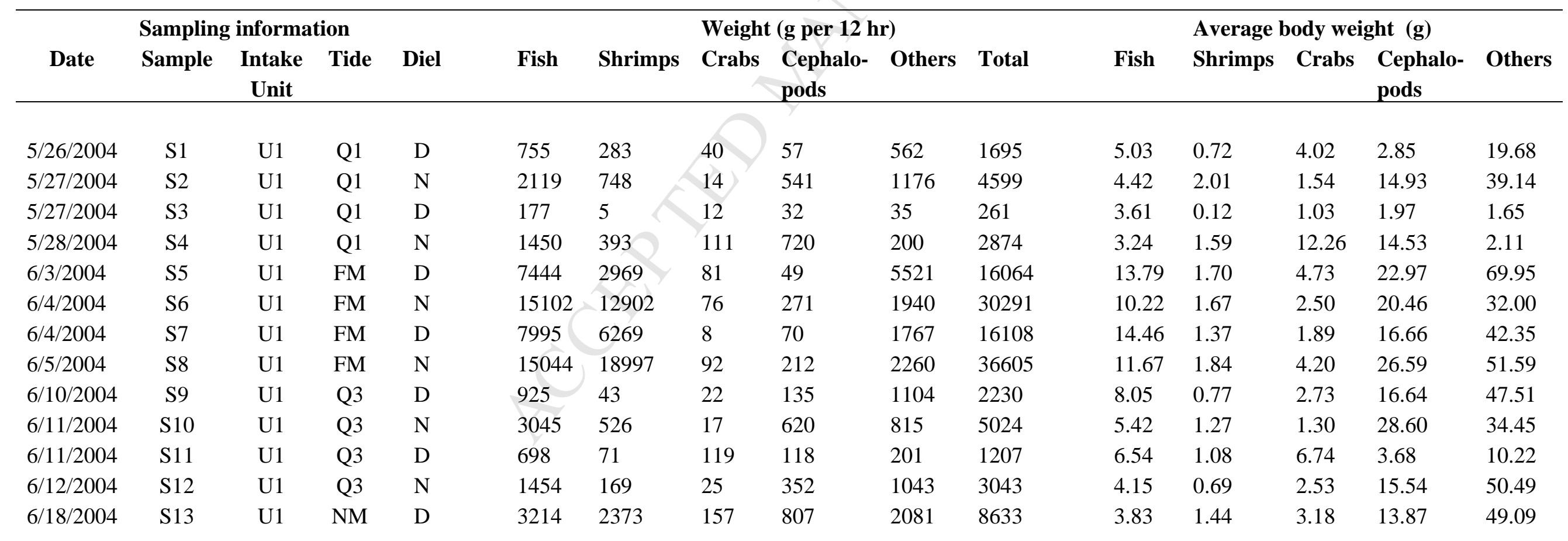




\begin{tabular}{|c|c|c|c|c|c|c|c|c|c|c|c|c|c|c|c|}
\hline $6 / 19 / 2004$ & S14 & U1 & $\mathrm{NM}$ & $\mathrm{N}$ & 3276 & 5706 & 119 & 664 & 856 & 10622 & 6.89 & 1.93 & 2.67 & 41.79 & 26.94 \\
\hline $6 / 19 / 2004$ & $\mathrm{~S} 15$ & U1 & NM & $\mathrm{D}$ & 2722 & 1594 & 131 & 401 & 231 & 5078 & 6.87 & 1.50 & 4.02 & 17.84 & 7.78 \\
\hline $6 / 20 / 2004$ & $\mathrm{~S} 16$ & U1 & NM & $\mathrm{N}$ & 5124 & 4811 & 148 & 875 & 1383 & 12341 & 7.35 & 2.31 & 2.77 & 21.49 & 23.20 \\
\hline $6 / 25 / 2004$ & S17 & U6 & Q1 & $\mathrm{D}$ & 1835 & 407 & 788 & 472 & 762 & 4263 & 25.48 & 2.19 & 9.60 & 26.23 & 21.17 \\
\hline $6 / 26 / 2004$ & $\mathrm{~S} 18$ & U6 & Q1 & $\mathrm{N}$ & 4526 & 329 & 991 & 2305 & 1679 & 9831 & 11.24 & 2.64 & 6.39 & 8.12 & 7.38 \\
\hline $6 / 26 / 2004$ & S19 & U6 & Q1 & $\mathrm{D}$ & 606 & 764 & 99 & 430 & 4083 & 5983 & 12.91 & 2.05 & 4.42 & 7.26 & 47.59 \\
\hline $6 / 27 / 2004$ & $\mathrm{~S} 20$ & U6 & Q1 & $\mathrm{N}$ & 1187 & 219 & 185 & 1218 & 2227 & 5037 & 8.08 & 1.58 & 8.72 & 11.89 & 50.11 \\
\hline $7 / 2 / 2004$ & $\mathrm{~S} 21$ & U6 & FM & $\mathrm{D}$ & 4454 & 1580 & 550 & 1548 & 3188 & 11319 & 6.67 & 1.77 & 6.25 & 24.96 & 30.66 \\
\hline $7 / 3 / 2004$ & $\mathrm{~S} 22$ & U6 & FM & $\mathrm{N}$ & 8336 & 2611 & 216 & 1312 & 1614 & 14089 & 5.48 & 2.47 & 3.37 & 22.48 & 14.06 \\
\hline $7 / 3 / 2004$ & $\mathrm{~S} 23$ & U6 & FM & $\mathrm{D}$ & 3904 & 1820 & 289 & 647 & 3079 & 9740 & 8.42 & 1.99 & 3.69 & 13.28 & 31.60 \\
\hline $7 / 4 / 2004$ & S24 & U6 & FM & $\mathrm{N}$ & 5851 & 1329 & 128 & 1217 & 1935 & 10461 & 8.91 & 3.04 & 3.94 & 26.41 & 22.91 \\
\hline $4 / 9 / 2004$ & $\mathrm{~S} 25$ & U6 & Q3 & $\mathrm{D}$ & 2495 & 950 & 287 & 260 & 1107 & 5099 & 3.85 & 1.67 & 4.12 & 10.88 & 6.46 \\
\hline $4 / 10 / 2004$ & S26 & U6 & Q3 & $\mathrm{N}$ & 1874 & 576 & 35 & 648 & 1619 & 4753 & 4.42 & 1.58 & 1.55 & 20.31 & 11.50 \\
\hline $4 / 10 / 2004$ & S27 & U6 & Q3 & $\mathrm{D}$ & 468 & 157 & 12 & 239 & 2307 & 3182 & 2.34 & 1.20 & 2.74 & 15.70 & 18.64 \\
\hline $7 / 11 / 2003$ & $\mathrm{~S} 28$ & U6 & Q3 & $\mathrm{N}$ & 2739 & 247 & 37 & 145 & 2656 & 5824 & 2.99 & 1.80 & 2.44 & 6.45 & 28.87 \\
\hline $7 / 17 / 2004$ & S29 & U6 & NM & $\mathrm{D}$ & 4073 & 1070 & 271 & 961 & 3544 & 9919 & 8.68 & 2.31 & 6.28 & 15.30 & 19.42 \\
\hline $7 / 18 / 2004$ & S30 & U6 & $\mathrm{NM}$ & $\mathrm{N}$ & 3893 & 715 & 108 & 496 & 807 & 6018 & 7.96 & 2.26 & 10.48 & 30.03 & 5.14 \\
\hline $7 / 18 / 2004$ & S31 & U6 & NM & $\mathrm{D}$ & 165 & 473 & 261 & 198 & 35138 & 36236 & 4.10 & 1.88 & 14.42 & 49.26 & 44.07 \\
\hline \multirow[t]{3}{*}{$7 / 19 / 2004$} & $\mathrm{~S} 32$ & U6 & $\mathrm{NM}$ & $\mathrm{N}$ & 3873 & 475 & 107 & 808 & 3130 & 8393 & 9.74 & 2.28 & 3.58 & 18.92 & 38.30 \\
\hline & & & & Mean: & 3776 & 2237 & 173 & 588 & 2814 & 9588 & 7.51 & 1.77 & 5.04 & 14.83 & 28.22 \\
\hline & & & & SE: & 3685 & 4012 & 221 & 510 & 6026 & 9140 & 0.80 & 0.11 & 0.57 & 1.81 & 3.06 \\
\hline
\end{tabular}


Table 2.

Estimated annual loss of marine organisms and species most vulnerable to impingement at Kapar Power Station, Malaysia.

\begin{tabular}{|c|c|c|c|c|c|c|}
\hline Group & Species / Taxa & Frequency & $\begin{array}{l}\text { Projected } \\
\text { annual loss } \\
\text { (abundance) }\end{array}$ & $\begin{array}{l}\text { Percentage } \\
\text { of total } \\
\text { abundance }\end{array}$ & $\begin{array}{l}\text { Projected } \\
\text { annual } \\
\text { loss }(\mathrm{kg})\end{array}$ & $\begin{array}{l}\text { Percentage } \\
\text { of total } \\
\text { biomass }\end{array}$ \\
\hline FISH (87 species) & $\begin{array}{l}\text { Ambassis } \\
\quad \text { gymnocephalus }\end{array}$ & $25 / 32$ & 421,967 & 4.96 & 1,045 & 2.49 \\
\hline $\begin{array}{l}\text { Total abundance } \\
\text { loss }=2,202,182\end{array}$ & $\begin{array}{l}\text { Thryssa } \\
\quad \text { kammalensis }\end{array}$ & $32 / 32$ & 259,921 & 0.29 & 662 & 1.58 \\
\hline $\begin{array}{l}\text { individuals or } \\
25.9 \% \text { of total }\end{array}$ & $\begin{array}{l}\text { Leiognathus } \\
\text { splendens }\end{array}$ & $29 / 32$ & 245,701 & 2.89 & 617 & 1.47 \\
\hline annual & Arius sagor & $28 / 32$ & 166,918 & 1.96 & 5,257 & 12.52 \\
\hline impingement & Scatophagus argus & $28 / 32$ & 143,272 & 1.67 & 2,068 & 4.92 \\
\hline \multirow{9}{*}{$\begin{array}{l}\text { Total biomass } 1 \\
=16,537 \mathrm{~kg} \text { or } \\
39.4 \% \text { of total } \\
\text { annual } \\
\text { impingement }\end{array}$} & $\begin{array}{l}\text { Gerres } \\
\quad \text { erythrourus }\end{array}$ & $28 / 32$ & 112,699 & 1.32 & 437 & 1.04 \\
\hline & $\begin{array}{l}\text { Dendophysa } \\
\text { russelii }\end{array}$ & $24 / 32$ & 74,184 & 0.87 & 402 & 0.96 \\
\hline & Arius maculatus & $24 / 32$ & 53,854 & 0.63 & 300 & 0.72 \\
\hline & Liza subviridis & $24 / 32$ & 40,198 & 0.47 & 759 & 1.81 \\
\hline & Pampus argenteus & $19 / 32$ & 38,751 & 0.46 & 114 & 0.27 \\
\hline & $\begin{array}{l}\text { Lepturacanthus } \\
\quad \text { savala }\end{array}$ & $27 / 32$ & 37,742 & 0.44 & 186 & 0.44 \\
\hline & Pomadasys kaakan & $14 / 32$ & 33,951 & 0.40 & 207 & 0.49 \\
\hline & $\begin{array}{l}\text { Herklotsichthys } \\
\text { punctatus }\end{array}$ & $13 / 32$ & 28,755 & 0.34 & 31 & 0.07 \\
\hline & $\begin{array}{c}\text { Anodontostoma } \\
\text { chacunda }\end{array}$ & $20 / 32$ & 27,542 & 0.32 & 63 & 0.15 \\
\hline \multirow[t]{2}{*}{$\begin{array}{l}\text { SHRIMPS (22 } \\
\text { species) }\end{array}$} & $\begin{array}{l}\text { Metapenaeus } \\
\text { affinis }\end{array}$ & $31 / 32$ & 846,711 & 9.95 & 1,437 & 3.42 \\
\hline & $\begin{array}{l}\text { Penaeus } \\
\quad \text { merguiensis }\end{array}$ & $28 / 32$ & 409,731 & 4.82 & 1,425 & 3.39 \\
\hline \multirow{3}{*}{$\begin{array}{l}\text { Total abundance } \\
\text { loss }=5,492,657 \text { or } \\
64.5 \% \text { of total } \\
\text { annual } \\
\text { impingement }\end{array}$} & $\begin{array}{c}\text { Metapenaeus } \\
\text { brevicornis }\end{array}$ & $31 / 32$ & 324,659 & 3.82 & 583 & 1.39 \\
\hline & $\begin{array}{l}\text { Parapenaeopsis } \\
\text { sculptilis }\end{array}$ & $28 / 32$ & 89,026 & 1.05 & 223 & 0.53 \\
\hline & Acetes sp. & $24 / 32$ & 69,815 & 1.05 & 21 & 0.05 \\
\hline \multirow{3}{*}{$\begin{array}{l}\text { Total biomass loss } \\
=9,658 \mathrm{~kg} \text { or } \\
23.0 \% \text { of total } \\
\text { annual } \\
\text { impingement }\end{array}$} & $\begin{array}{l}\text { Palaemon } \\
\text { styliferus }\end{array}$ & $21 / 32$ & 55,173 & 0.64 & 75 & 0.18 \\
\hline & $\begin{array}{c}\text { Parapenaeopsis } \\
\text { maxillipedo }\end{array}$ & $22 / 32$ & 49,377 & 0.58 & 53 & 0.13 \\
\hline & Metapenaeus ensis & $25 / 32$ & 49,315 & 0.58 & 107 & 0.25 \\
\hline \multirow{5}{*}{$\begin{array}{l}\text { STOMATOPODS } \\
\text { (7 species) } \\
\text { Total abundance } \\
\text { loss }=53,655 \text { or } \\
0.6 \% \text { of total } \\
\text { annual } \\
\text { impingement }\end{array}$} & $\begin{array}{r}\text { Oratosquilla } \\
\text { interrupta }\end{array}$ & $12 / 32$ & 6,858 & 0.08 & 48 & 0.11 \\
\hline & Cloridopsis & $7 / 32$ & 3,856 & 0.05 & 19 & 0.05 \\
\hline & $\begin{array}{c}\text { scorpio } \\
\text { Clorida sp. }\end{array}$ & $7 / 32$ & 3.064 & $0 \Omega 4$ & 1 & 002 \\
\hline & Miyakea nepa & $4 / 32$ & 2,682 & 0.03 & 14 & 0.03 \\
\hline & $\begin{array}{l}\text { Dictyosquilla } \\
\text { foveolata }\end{array}$ & $3 / 32$ & 1,644 & 0.02 & 12 & 0.03 \\
\hline
\end{tabular}




\begin{tabular}{|c|c|c|c|c|c|c|}
\hline Group & Species / Taxa & Frequency & $\begin{array}{l}\text { Projected } \\
\text { annual loss } \\
\text { (abundance) }\end{array}$ & $\begin{array}{l}\text { Percentage } \\
\text { of total } \\
\text { abundance }\end{array}$ & $\begin{array}{l}\text { Projected } \\
\text { annual } \\
\text { loss }(\mathrm{kg})\end{array}$ & $\begin{array}{l}\text { Percentage } \\
\text { of total } \\
\text { biomass }\end{array}$ \\
\hline $\begin{array}{l}\text { Total biomass loss } \\
=139 \mathrm{~kg} \text { or } 0.3 \% \\
\text { of total annual } \\
\text { impingement }\end{array}$ & $\begin{array}{c}\text { Oratosquilla } \\
\text { perpensa }\end{array}$ & $4 / 32$ & 1,407 & 0.02 & 13 & 0.03 \\
\hline $\begin{array}{l}\text { CRABS (17 } \\
\text { species) }\end{array}$ & $\begin{array}{l}\text { Charybdis } \\
\text { japonica }\end{array}$ & $29 / 32$ & 46,877 & 0.55 & 102 & 0.24 \\
\hline Total abundance & $\begin{array}{l}\text { Neodorippe } \\
\text { callida }\end{array}$ & $28 / 32$ & 34,319 & 0.40 & 26 & 0.06 \\
\hline $\begin{array}{l}\text { loss }=150,426 \text { or } \\
1.8 \% \text { of total }\end{array}$ & $\begin{array}{r}\text { Myomenippe } \\
\text { hardwicki }\end{array}$ & $14 / 32$ & 16,338 & 0.19 & 202 & 0.48 \\
\hline annual & Matuta planipes & $17 / 32$ & 15,761 & 0.19 & 27 & 0.06 \\
\hline impingement & Doclea ovis & $17 / 32$ & 9,559 & 0.11 & 22 & 0.05 \\
\hline Total biomass loss & $\begin{array}{l}\text { Portunus } \\
\quad \text { pelagicus }\end{array}$ & $13 / 32$ & 3,722 & 0.04 & 40 & 0.09 \\
\hline & $\begin{array}{l}\text { Charybdis } \\
\text { anisodon }\end{array}$ & $6 / 32$ & 2,746 & 0.03 & 69 & 0.16 \\
\hline impingement & $\begin{array}{l}\text { Scylla } \\
\quad \text { paramamosain }\end{array}$ & $4 / 32$ & 825 & 0.00 & 64 & 0.15 \\
\hline CEPHALOPODS & Sepiella inermis & $30 / 32$ & 108,201 & 1.27 & 1,944 & 4.63 \\
\hline (3 species) & $\begin{array}{l}\text { Loligo sp. } \\
\text { Octopus sp. }\end{array}$ & $\begin{array}{l}24 / 32 \\
22 / 32\end{array}$ & $\begin{array}{l}53,463 \\
12,096\end{array}$ & $\begin{array}{l}0.63 \\
0.14\end{array}$ & $\begin{array}{l}126 \\
502\end{array}$ & $\begin{array}{l}0.30 \\
1.20\end{array}$ \\
\hline $\begin{array}{l}\text { Total abundance } \\
\text { loss = } 173,694 \text { or } \\
2.0 \% \text { of total } \\
\text { annual } \\
\text { impingement }\end{array}$ & & & & & & \\
\hline $\begin{array}{l}\text { Total biomass loss } \\
=2,577 \mathrm{~kg} \text { or } 6.1 \% \\
\text { of total annual } \\
\text { impingement }\end{array}$ & & & & & & \\
\hline $\begin{array}{l}\text { OTHERS (42 } \\
\text { species) }\end{array}$ & $\begin{array}{l}\text { Salmacis } \\
\quad \text { dussumieri }\end{array}$ & $30 / 32$ & 130,227 & 1.53 & 605 & 1.44 \\
\hline & Lobonema smithii & $6 / 32$ & 100,400 & 1.18 & 3,583 & 8.53 \\
\hline Total abundance & Thais tissoti & $29 / 32$ & 51,445 & 0.60 & 84 & 0.20 \\
\hline $\begin{array}{l}\text { loss }=436,769 \text { or } \\
5.1 \% \text { of total }\end{array}$ & $\begin{array}{c}\text { Carcinoscorpius } \\
\text { rotundicauda }\end{array}$ & $23 / 32$ & 22,178 & 0.26 & 1,804 & 2.30 \\
\hline annual & Sea cucumber E & $16 / 32$ & 19,317 & 0.22 & 62 & 0.15 \\
\hline impingement & Perna viridis & $28 / 32$ & 17,599 & 0.19 & 101 & 0.24 \\
\hline & Natica maculosa & $16 / 32$ & 16,176 & 0.19 & 34 & 0.08 \\
\hline $\begin{array}{l}\text { Total biomass loss } \\
=12,326 \mathrm{~kg} \text { or } \\
29.4 \% \text { of total } \\
\text { annual } \\
\text { impingement }\end{array}$ & Ophiuroidea & $2 / 32$ & 16,002 & 0.19 & 5 & 0.01 \\
\hline
\end{tabular}


Table 3. List of total species number, major species and estimated annual impingement of fish in selected power stations of the world. Invertebrates (in parentheses) are included where information is available.

\begin{tabular}{|c|c|c|c|c|c|c|c|c|c|c|}
\hline & Power Plant & Location & $\begin{array}{l}\text { Capacity } \\
\text { (MW) }\end{array}$ & Year (period) & $\begin{array}{l}\text { Numbers } \\
\text { Impinged }\end{array}$ & $\begin{array}{r}\text { Estimated } \\
\text { Annual } \\
\text { mpingement }\end{array}$ & $\begin{array}{r}\text { No. of } \\
\text { Species }\end{array}$ & $\begin{array}{l}\text { Common name } \\
\text { of main species }\end{array}$ & $\%$ & Source \\
\hline & USA & & & & & & & & & \\
\hline 1 & Comanche Peak & Caddo Lake, Texas & 2300 & $1993-94(1 \mathrm{yr})$ & & 262,498 & 13 & Threadfin shad & 96 & Spicer et al. (2000) \\
\hline & & & & & & & & Bluegill sunfish & 2 & \\
\hline \multirow[t]{2}{*}{2} & Quad Cities & Mississippi River, Illinois/lowa & 1630 & $1984-94$ & & $232,000-$ & & Gizzard shad & 66 & LaJeone et al. (2000) \\
\hline & & & & & & $2,989,000$ & & Freshwater drum & 21 & \\
\hline \multirow[t]{3}{*}{3} & Chalk Point & Patuxent River, Maryland & 2423 & 1976-1977 & & $4,316,456$ & & Atlantic menhaden & 31 & Richkus et al. (2000) \\
\hline & & & & & & & & Spot & 15 & \\
\hline & & & & & & & & (Blue crab) & 45 & \\
\hline \multirow[t]{3}{*}{4} & Davies-Besse & Lake Erie, Oak Harbor, Ohio & 889 & 1977 (4 mo) & 1936 & & 15 & Gizzard shad & 45 & Reuter (1978) \\
\hline & & & & & & & & Freshwater drum & 12 & \\
\hline & & & & & & & & White crappies & 12 & \\
\hline \multirow[t]{3}{*}{5} & Cayuga & Wabash River, Indiana & 1075 & $1987-88(6 \mathrm{mo})$ & 1036 & & 14 & Gizzard shad & 59 & Lewis \& Seggert (2000) \\
\hline & Wabash & Wabash River, Indiana & 930 & & 936 & 13,157 & & Channel catfish & 32 & \\
\hline & & & & & & & & Minnows & & \\
\hline \multirow[t]{2}{*}{7} & Oak Creek & Lake Michigan, Wisconsin & 1211 & $1975-76$ & & $2,754,000$ & & Alewife & 78 & Michaud (2000) \\
\hline & & & & & & & & Rainbow smelt & 21 & \\
\hline \multirow[t]{2}{*}{8} & Presque Isle & Lake Superior, Wisconsin & 617 & $1975-76$ & 4,762 & $4762 ?$ & 21 & Rainbow smelt & 87 & Michaud (2000) \\
\hline & & & & & & & & Burbot & 4 & \\
\hline \multirow[t]{3}{*}{9} & Calvert Cliffs & Chesapeake Bay, Maryland & 1700 & $1975-1995$ (21 yr) & & $79,000-$ & 73 & 5 main species & $>90$ & Ringger (2000) \\
\hline & & & & & & $9,600,000$ & $(20-51 / y r)$ & (including & & \\
\hline & & & & & & (mean= & & Bay anchovy \& & & \\
\hline
\end{tabular}




\section{UK \& EUROPE}

10 Longganet

11 Pembroke

Daugleddau estuary,

2000

1997 (2 mo)

England

12 Sizewell A

13 Coolkeeragh

Suffolk coast, England

1200

1981-82 ( 1 yr)

Derry, northern Ireland

14 Oldbury-Upon Severn

Severn estuary, England

16 Hinkley Point B

17 Kilroot

18 Gravelines

19 Eems
Southhampton, England

Bristol Channel, England

Belfast Lough, North Ireland

520

North Sea, Nord, France

Eems estuary, Netherlands
$=1,300,000$

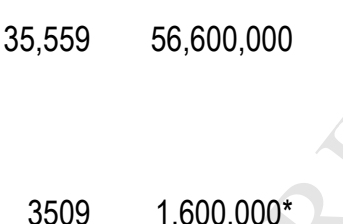

3509

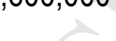

$3,700,000$

$1,700,000$

250,000

600,000

990,000

110,000

$214,000,000$

$18,000,000$

hogchoker)

40

38

(1)

400

434

1989-90 (1 yr)

$1971-76(5 \mathrm{yr})$

2000

1973-74 (1 yr)

1250

$16 \mathrm{yr}$

28

75

80

73

37

$5706 \quad 1981-82(2 \mathrm{yr})$

$1700 \quad 1996-7(1 \mathrm{yr})$
Thick-lipped mullet 10

Nilsson's fish 9

$\begin{array}{rll}\text { Herring } & 30-49 & \text { Greenwood (2008) } \\ \text { Sprat } & 36-48 & \\ \text { Whiting } & 5-9 & \\ & & \text { Turnpenny et al. (1997) } \\ \text { 3-spined } & & \\ \text { ed mullet } & 10 & \\ \text { son's fish } & 9 & \end{array}$

Turnpenny et al. (1983)*

Moorehead \& Service (1992)*

Claridge et al. (1986)*

Holmes (1975)*

Henderson (2009)

Moorehead \& Service (1992)*

Blanpied-Wohrer (1984)*

Herring 28

Gobies 50

3-spined

stickleback 7

Nilson's pipefish 4 
ASIA

2nd Nuclear Power

21 Plant

Kuosheng, Taiwan

1960

2000-4 (45 mo)

9,735

Rabbitfish 63

1987-90 (34 mo)

8,258

(4-31/mo)

(5-48/mo)

Karachi Nuclear

22 Power

Karachi, Pakistan

1974-77 (4 yr)

62

Spiny pufferfish 20

Plant

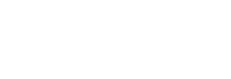

23 Kapar Power Station

Kapar, Malaysia

2420

2004 (2 mo)

62,169

2,202,182

(total biota $=$

$8,500,000)$

87
(total biota $=$
187 species)

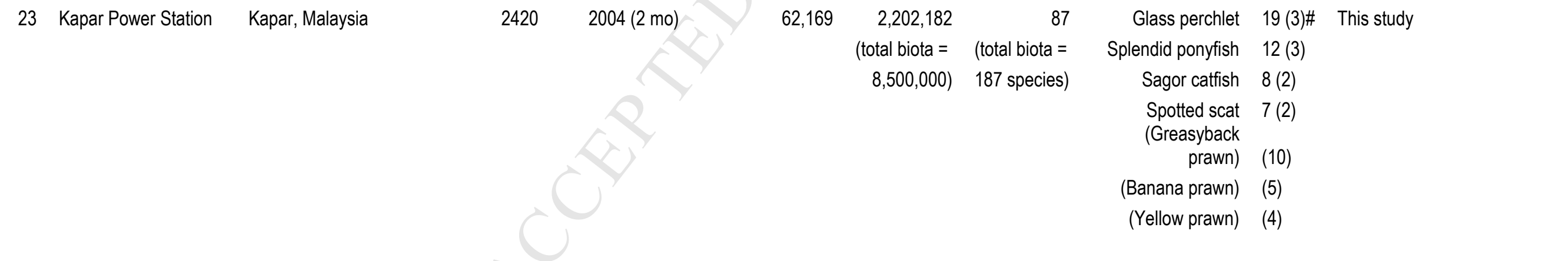

Terapon

Grey mullet

Banded sergeant

Smooth blaasop

Sardinella

Moazzam \& Rizvi (1980)

\# number in parenthesis indicates $\%$ of total impinged

biota

* in Henderson (2009) 


\section{$\underline{\text { Legend to Figures }}$}

Figure 1.

Location of Kapar Power Station (KPS), Selangor state, Malaysia.

Figure 2.

Curve of cumulative species number against sampling effort for Kapar Power Station screens. Dash line = fish; round dotted line = invertebrates; solid line = all biota; filled histogram $=$ number of fish species; empty histogram $=$ number of invertebrate species .

Figure 3 .

Radar plots of abundance of impinged organisms (no./12hr) at Unit 1 (top 2 rows) and Unit 6 (bottom 2 rows) at Kapar Power Station, Malaysia, by faunal group, moon phase $\left(\mathrm{q} 1, \mathrm{Q} 1=1^{\text {st }}\right.$ quarter; fm, $\mathrm{FM}=$ full moon; $\mathrm{q} 3, \mathrm{Q} 3=3^{\text {rd }}$ quarter; $\mathrm{nm}, \mathrm{NM}=$ new moon $)$ and light condition $($ day time $=$ small letters, night time $=$ block letters $)$. Vertical scale $=$ abundance/12 hr.

Figure 4.

Average percentage weight of damaged marine organisms compared to those in good condition for five faunal groups impinged at Kapar Power Station, Malaysia. 


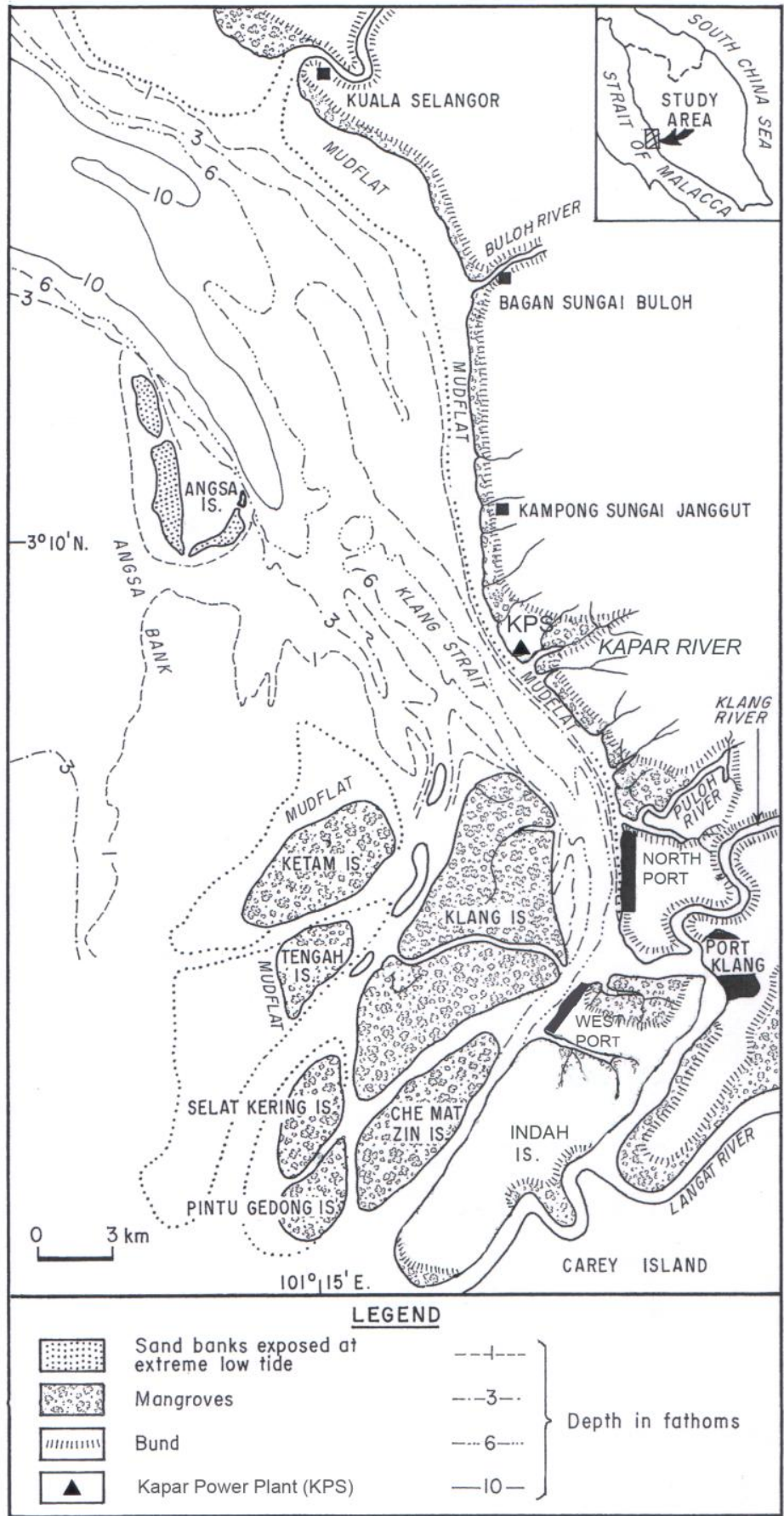




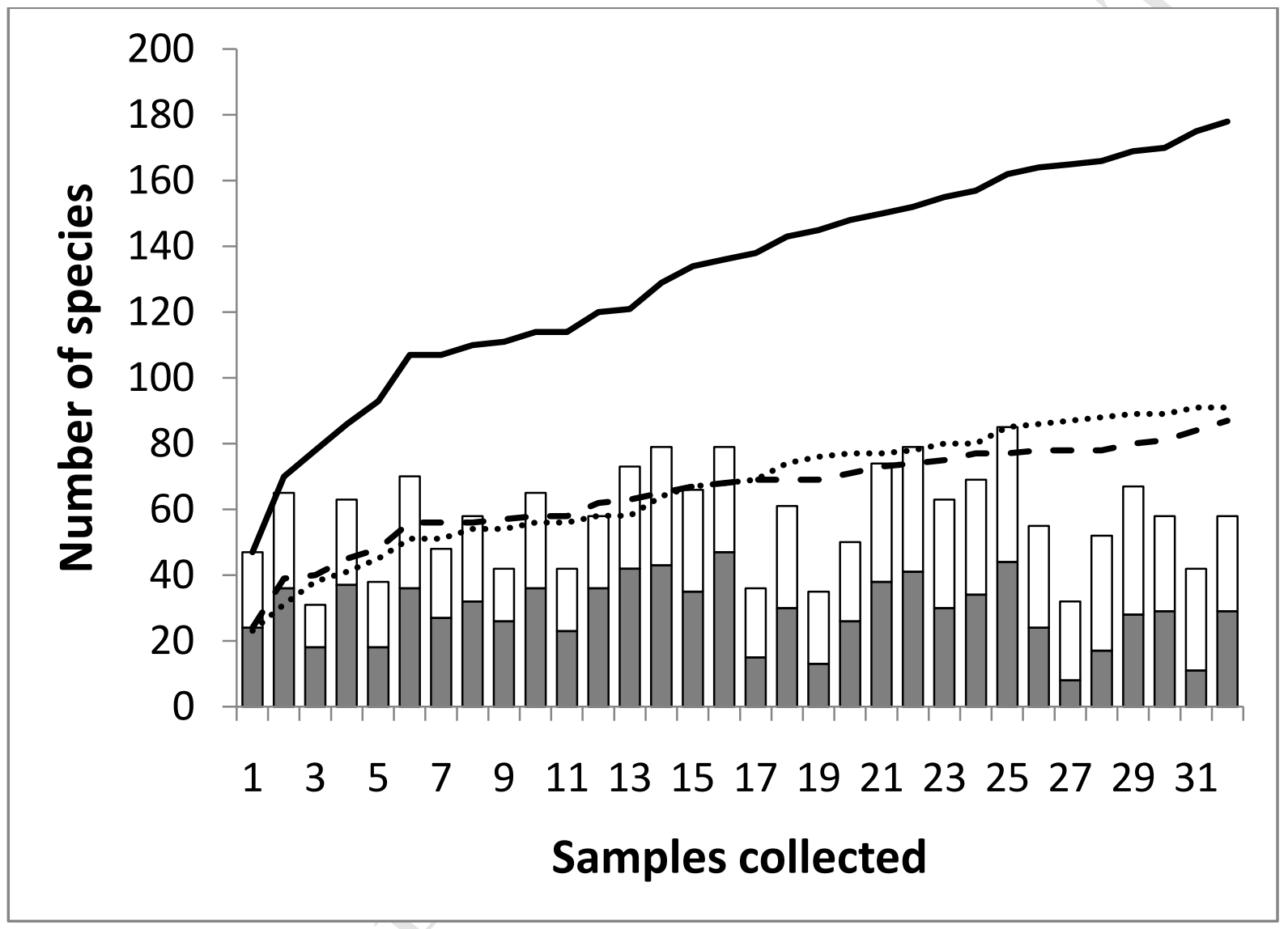


Figure3

Click here to download high resolution image ACCEPTED MANUSCRIPT

Sthrimp
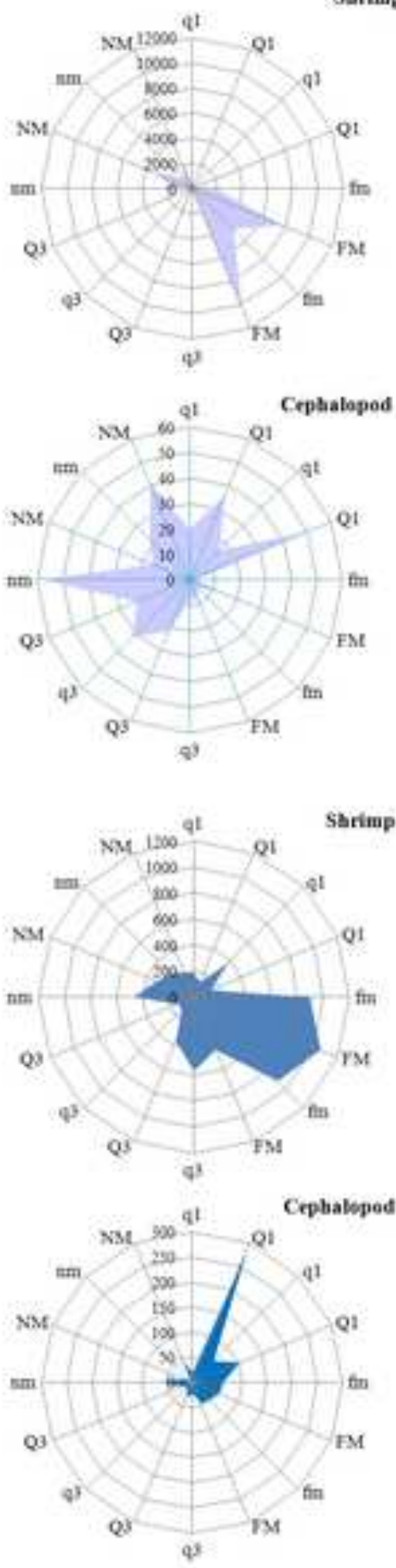

Fish

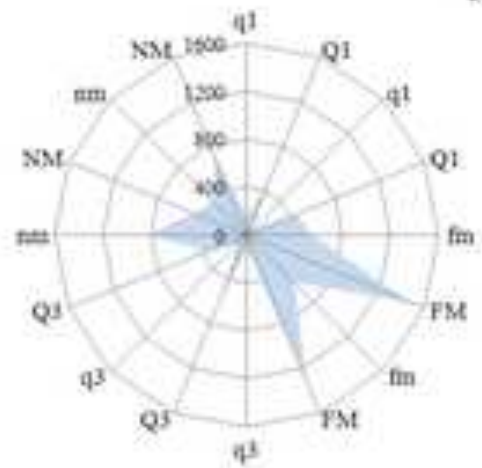

Oiters
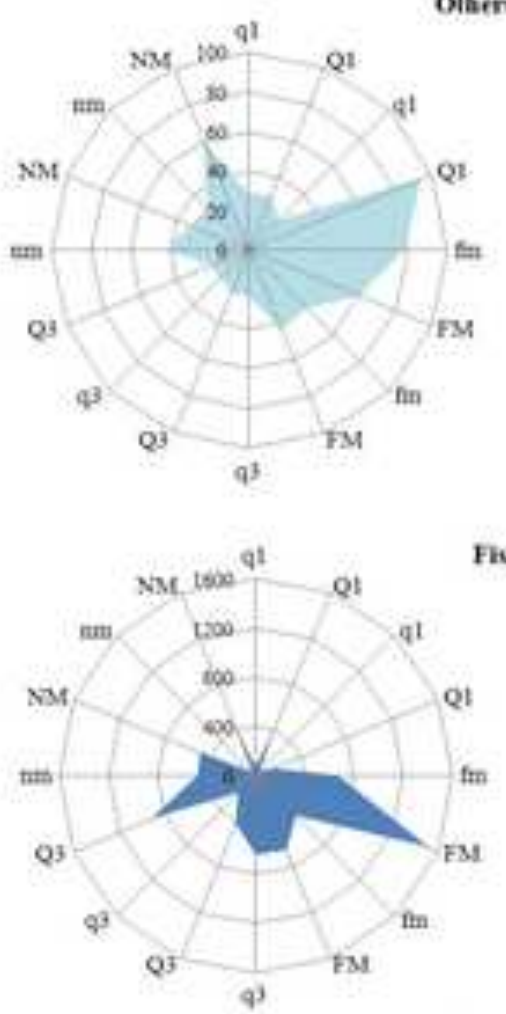

Fih

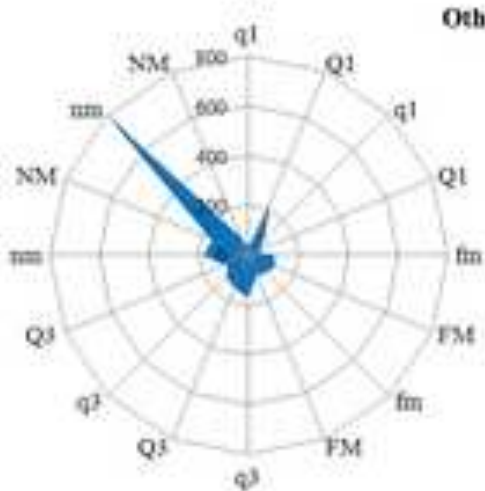

Crab

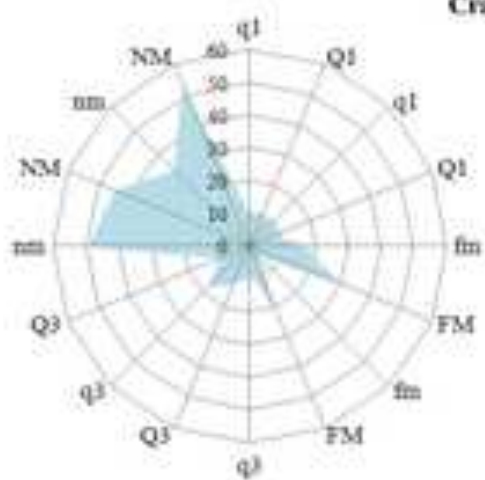

Total
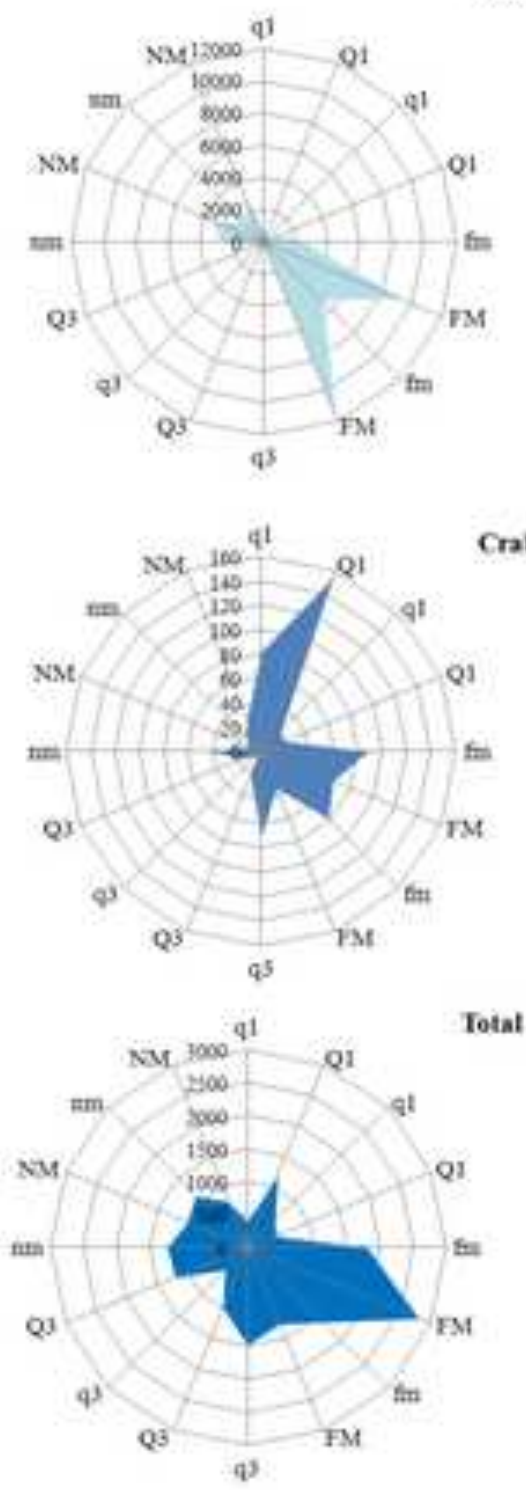

Total 


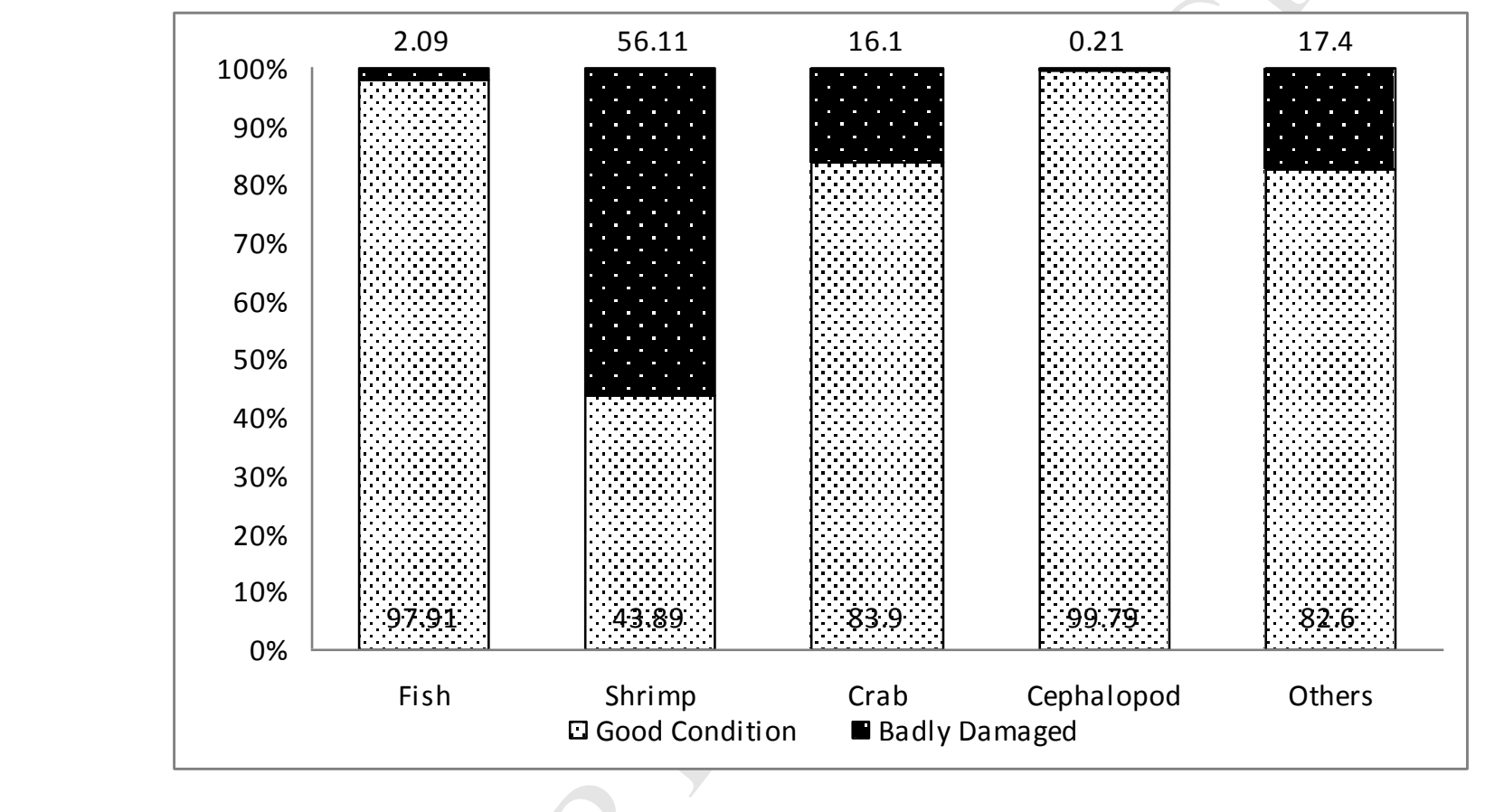

Fig.4

Figure4
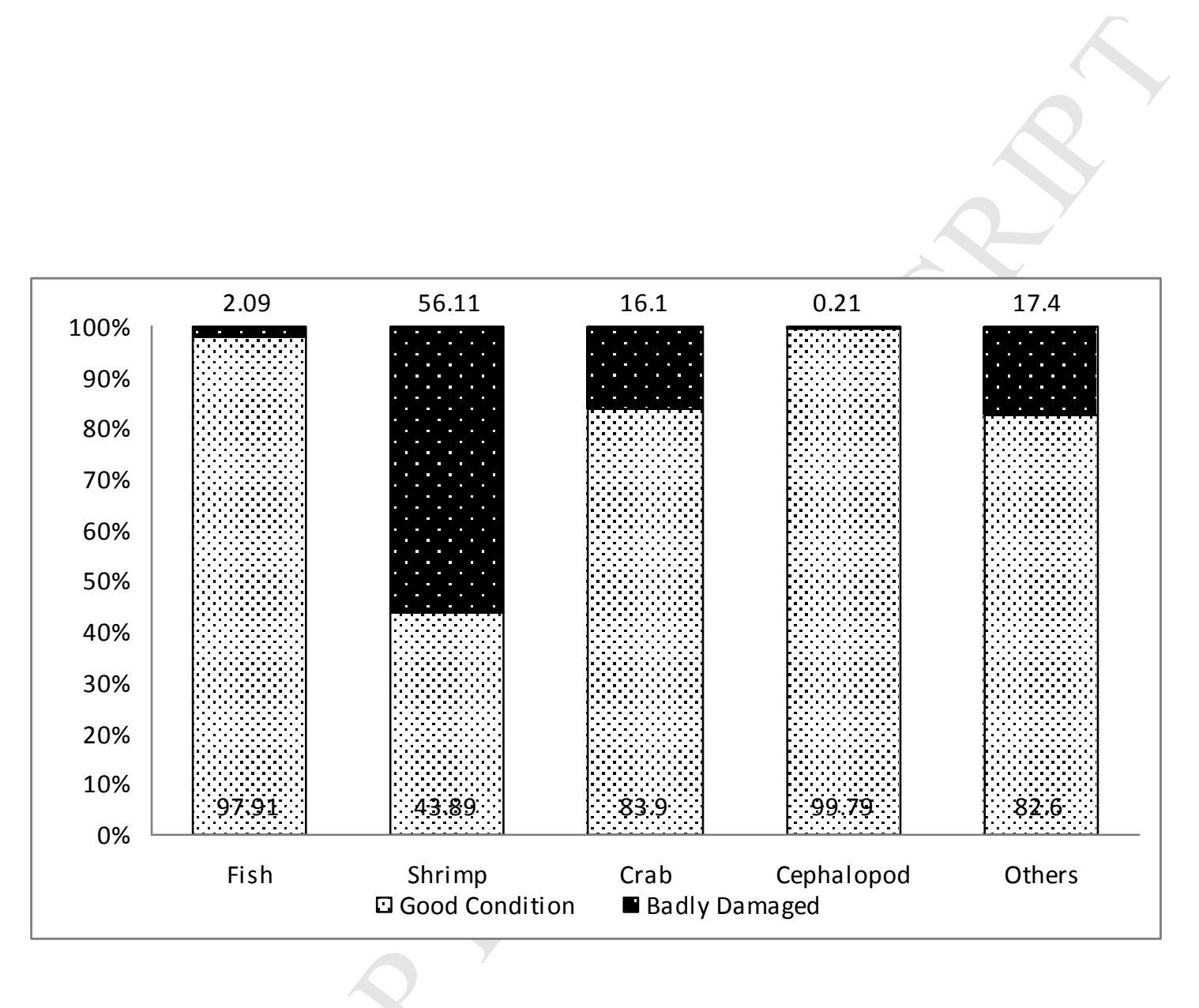

\section{(2)}
(a)

Figure4

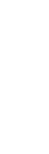


Appendix A.

List of impinged species sampled from cooling water intakes of Kapar Power Station, May 26 - July 19, 2004, ranked in order of total abundance.

\begin{tabular}{|c|c|c|c|c|c|c|c|}
\hline & & Species & $\begin{array}{l}\text { Family/ Higher } \\
\text { Taxa }\end{array}$ & Common Name & Abundance & $\begin{array}{c}\text { Biomass } \\
\mathrm{g} \\
\end{array}$ & $\begin{array}{c}\text { Frequency } \\
\% \\
\end{array}$ \\
\hline 1 & $* *$ & Metapenaeus affinis & Penaeidae & Greasy back shrimp & 6186 & 10498 & 97 \\
\hline 2 & & Ambassis gymnocephalus & Ambassidae & Glass perchlet & 3083 & 7636 & 78 \\
\hline 3 & $* *$ & Penaeus merguiensis & Penaeidae & Banana prawn & 2993 & 10411 & 88 \\
\hline 4 & $* *$ & Metapenaeus brevicornis & Penaeidae & Yellow prawn & 2372 & 4261 & 97 \\
\hline 5 & $*$ & Thryssa kammalensis & Engraulidae & Kammal thryssa & 1899 & 4840 & 100 \\
\hline 6 & $* *$ & Leiognathus splendens & Leiognathidae & Splendid ponyfish & 1795 & 4507 & 91 \\
\hline 7 & $*$ & Arius sagor & Ariidae & Sagor catfish & 1219 & 38410 & 88 \\
\hline 8 & $*$ & Scatophagus argus & Scatophagidae & Spotted scat & 1047 & 15107 & 88 \\
\hline 9 & & Salmacis dussumieri & Temopleuridae & Sea urchin & 951 & 4416 & 94 \\
\hline 10 & $* *$ & Gerres erythrourus & Gerreidae & Deep-bodied mojarra & 823 & 3195 & 88 \\
\hline 11 & $* *$ & Sepiella inermis & Sepiidae & Spineless cuttlefish & 791 & 14199 & 94 \\
\hline 12 & $* *$ & Lobonema smithii & Rhizostomeae & White jellyfish & 734 & 26176 & 19 \\
\hline 13 & $* *$ & Parapenaeopsis sculptilis & Penaeidae & Rainbow prawn & 650 & 1631 & 88 \\
\hline 14 & $* *$ & Dendrophysa russelii & Sciaenidae & Goatee croaker & 542 & 2933 & 75 \\
\hline 15 & $* *$ & Acetes sp. & Sergestidae & Sergestid shrimp & 510 & 150 & 75 \\
\hline 16 & $* *$ & Palaemon styliferus & Palaemonidae & Caridean shrimp & 403 & 550 & 66 \\
\hline 17 & $*$ & Arius maculatus & Ariidae & Spotted catfish & 393 & 2195 & 75 \\
\hline 18 & $* *$ & Loligo sp. & Loliginidae & Pencil squid & 391 & 923 & 75 \\
\hline 19 & & Thais tissoti & Muricidae & Tissot's rockshell & 376 & 614 & 91 \\
\hline 20 & $* *$ & Parapenaeopsis maxillipedo & Penaeidae & Torpedo shrimp & 361 & 385 & 69 \\
\hline 21 & $* *$ & Metapenaeus ensis & Penaeidae & Pink prawn & 360 & 782 & 78 \\
\hline 22 & $*$ & Charybdis japonica & Portunidae & Japanese swimming crab & 342 & 742 & 91 \\
\hline 23 & $* *$ & Parapenaeopsis coromandelica & Penaeidae & Coromandel shrimp & 318 & 463 & 59 \\
\hline 24 & $* *$ & Parapenaeopsis gracillima & Penaeidae & Thin shrimp & 302 & 332 & 66 \\
\hline 25 & $* *$ & Liza subviridis & Mugilidae & Greenback mullet & 294 & 5546 & 75 \\
\hline 26 & $* *$ & Pampus argenteus & Stromateidae & Silver pomfret & 283 & 830 & 59 \\
\hline 27 & $* *$ & Lepturacanthus savala & Trichiuridae & Savalani hairtail & 276 & 1360 & 84 \\
\hline 28 & & Neodorippe callida & Dorippidae & Leaf porter crab & 251 & 186 & 88 \\
\hline 29 & $* *$ & Pomadasys kaakan & Haemulidae & Javelin grunter & 248 & 1510 & 44 \\
\hline 30 & $*$ & Herklotsichthys punctatus & Clupeidae & Spotback herring & 210 & 228 & 41 \\
\hline 31 & $*$ & Anodontostoma chacunda & Clupeidae & Chacunda gizzard shad & 201 & 459 & 63 \\
\hline 32 & $* *$ & Cynoglossus lingua & Cynoglossidae & Long tongue sole & 191 & 1334 & 66 \\
\hline 33 & $* *$ & Johnius borneensis & Sciaenidae & Sharptooth hammer croaker & 188 & 1415 & 75 \\
\hline 34 & & Tetraodon fluviatilis & Tetraodontidae & Estuarine blowfish & 182 & 4109 & 72 \\
\hline 35 & $*$ & Macrobrachium equidens & Palaemonidae & Rough river prawn & 171 & 701 & 72 \\
\hline 36 & & Carcinoscorpius rotundicauda & Xiphosura & Horseshoe crab & 162 & 13180 & 72 \\
\hline 37 & $* *$ & Drepane longimana & Drepaneidae & Banded sicklefish & 150 & 641 & 72 \\
\hline 38 & & Oxuderces dentatus & Gobiidae & Goby & 147 & 681 & 47 \\
\hline 39 & & Sea cucumber sp. E & Holothuroidea & Sea cucumber & 141 & 453 & 50 \\
\hline 40 & $* *$ & Johnius belangerii & Sciaenidae & Belanger's croaker & 139 & 1526 & 47 \\
\hline 41 & $* *$ & Perna viridis & Mytilidae & Asian brown mussel & 129 & 736 & 88 \\
\hline 42 & $* *$ & Siganus vermiculatus & Siganidae & Vermiculated spinefoot & 127 & 143 & 53 \\
\hline 43 & $*$ & Myomenippe hardwickii & Eriphiidae & Mangrove stone crab & 119 & 1473 & 44 \\
\hline
\end{tabular}


* Natica marculosa

** Secutor insidiator Ophiuroid sp.

Matuta planipes

** Johnius carouna

** Octopus sp.

Butis koilomatodon

** Metapenaeus lysianassa

** Alepes djeddaba

** Plotosus canius

Doclea ovis

** Terapon theraps

Odontamblyopus sp.

Sea cucumber sp. B

Aniptumnus quadridentatus

Ctenotrypauchen microcephalus

** Harpadon nehereus

** Terapon jarbua

Boleophthalmus boddarti

Sea cucumber sp. F

** Parapenaeopsis tenella

** Oratosquilla interrupta

** Parapenaeopsis hungerfordi

* Alpheus sp.

** Scomberoides commersonnianus

* Coilia dussumieri

Tachypleus gigas

* Mimocaris sp.

* Ilisha melastoma

Sea cucumber sp. K

** Solen $\mathrm{sp}$.

** Lutjanus johnii

* Allenbatrachus grunniens Clorida sp.

** Portunus pelagicus

** Himantura bleekeri Jellyfish sp. 3

* Thryssa hamiltonii Nereis sp.

* Cloridopsis scorpio

** Eleutheronema tetradactylum Isopod species

Takifugu oblongus

* Charybdis anisodon

** Miyakea nepa

** Dasyatis zugei

** Cynoglossus punticeps

Sea cucumber sp. L

* Glossogobius giuris

** Sillago sihama

Jellyfish sp. 5

Jellyfish sp. 4

Eucrate sp.

Crepidula sp.
Naticidae

Leiognathidae

Ophiuroidea

Calappinae

Sciaenidae

Octopodidae

Eleotridae

Penaeidae

Carangidae

Plotosidae

Majidae

Terapontidae

Gobiidae

Holothuroidea

Pilumnidae

Gobiidae

Synodontidae

Terapontidae

Gobiidae

Holothuroidea

Penaeidae

Squillidae

Penaeidae

Alpheidae

Carangidae

Engraulidae

Xiphosura

Hippolytidae

Pristigasteridae

Holothuroidea

Slecurtidae

Lutjanidae

Batrachoididae

Squillidae

Portunidae

Dasyatidae

Scyphozoa

Engraulidae

Neridae

Squillidae

Polynemidae

Isopoda

Tetraodontidae

Portunidae

Squillidae

Dasyatidae

Cynoglossidae

Holothuroidea

Gobiidae

Sillaginidae

Scyphozoa

Scyphozoa

Geneplacidae

Calyptraeidae
Sand snails

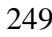

Pugnose ponyfish

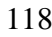

249

Brittle-stars

190

Flower moon crab

38

195

Caroun croaker

Benthic octopus

Saw-toothed gudgeon

Small white prawn

Djeddaba crevalle

Gray eel-catfish

Spider crab

Largescaled terapon

1772

3667

335

36

116

4993

Goby

Sea cucumber

Blind goby

Bombay-duck

257

305

Boddart's goggle-eyed goby

518

Sea cucumber

239

Smooth shell shrimp

Mantis shrimp

Banded sharp-rostrum prawn

Pistol prawn

Talang queenfish

Goldspotted grenadier anchovy

Horseshoe crab

Companion shrimp

Indian ilisha

Sea cucumber

Razor shell

John's snapper

Grunting toadfish

Mantis shrimp

Flower crab

Whip-tail stingray

Jellyfishes

Hamilton's anchovy/ thryssa

Polychaete worms

Spotted squillid mantis prawn

Fourfinger threadfin

Isopod

Oblong blowfish

Two-spine arm swimming crab

Smalleyed mantis shrimp

Pale edge stingray

Speckled tonguesole

Sea cucumber

Bar-eyed goby

Silver sillago

Jellyfish

Jellyfish

Goneplacid crab

Slipper limpet

50

59

6

53

69

69

56

6 


\begin{tabular}{|c|c|c|c|}
\hline 98 & $*$ & Triacanthus biaculeatus & Triacanthidae \\
\hline 99 & $* *$ & Charybdis feriatus & Portunidae \\
\hline 100 & & Hyastenus diacanthus & Majidae \\
\hline 101 & $* *$ & Harpiosquilla harpax & Harpiosquillidae \\
\hline 102 & & Lagocephalus lunaris & Lagocephalidae \\
\hline 103 & $*$ & Setipinna taty & Engraulidae \\
\hline 104 & $* *$ & Nibea soldado & Sciaenidae \\
\hline 105 & & Bursa sp. & Bursidae \\
\hline 106 & & Medaeops potens & Xanthidae \\
\hline 107 & $* *$ & Dictyosquilla foveolata & Squillidae \\
\hline 108 & $*$ & Liza melinoptera & Mugilidae \\
\hline 109 & & Stegostoma fasciatum & Stegostomatidae \\
\hline 110 & $*$ & Zenarchopterus dispar & Hemirhamphidae \\
\hline 111 & $* *$ & Oratosquilla perpensa & Squillidae \\
\hline 112 & & Sea cucumber sp. A & Holothuroidea \\
\hline 113 & & Eurythoe sp. & Polychaetes \\
\hline 114 & $*$ & Charybdis sp. & Portunidae \\
\hline 115 & $* *$ & Otolithes ruber & Sciaenidae \\
\hline 116 & & Sea cucumber sp. D & Holothuroidea \\
\hline 117 & & Jellyfish sp. 2 & Scyphozoa \\
\hline 118 & $* *$ & Alepes sp. & Carangidae \\
\hline 119 & & Scartelaos histophorus & Gobiidae \\
\hline 120 & & Sea cucumber sp. G & Holothuroidea \\
\hline 121 & $*$ & Arius venosus & Ariidae \\
\hline 122 & $* *$ & Scylla paramamosain & Portunidae \\
\hline 123 & & Doclea rissoni & Majidae \\
\hline 124 & $*$ & Caridean sp. 2 & Palaemonidae \\
\hline 125 & $* *$ & Penaeus monodon & Penaeidae \\
\hline 126 & & Clibanaria infraspinatus & Paguridae \\
\hline 127 & & Kurtus indicus & Kurtidae \\
\hline 128 & & Sea cucumber sp. $\mathrm{H}$ & Holothuroidea \\
\hline 129 & $*$ & Osteogeneiosus militaris & Ariidae \\
\hline 130 & & Dorippoides facchino & Dorippidae \\
\hline 131 & $* *$ & Taeniura lymna & Dasyatidae \\
\hline 132 & $* *$ & Parapenaeopsis hardwickii & Penaeidae \\
\hline 133 & & Calyptraea extinctorium & Calyptraeidae \\
\hline 134 & & Sea cucumber sp. I & Holothuroidea \\
\hline 135 & & Sea cucumber sp. M & Holothuroidea \\
\hline 136 & $* *$ & Johnius amblycephalus & Sciaenidae \\
\hline 137 & & Benthopanope sp. & Pilumnidae \\
\hline 138 & $*$ & Caridean sp. 1 & Palaemonidae \\
\hline 139 & & Sea cucumber sp. $\mathrm{N}$ & Holothuroidea \\
\hline 140 & $* *$ & Sideria thyrsoidea & Muraenidae \\
\hline 141 & $*$ & Hyporhamphus gaimardi & Hemirhamphidae \\
\hline 142 & & Vespicula trachinoides & Tetrarogidae \\
\hline 143 & $*$ & Thais carinifera & Muricidae \\
\hline 144 & $* *$ & Ilisha kampeni & Pristigasteridae \\
\hline 145 & $* *$ & Sphyraena jello & Sphyraenidae \\
\hline 146 & $* *$ & Dasyatis kuhlii & Dasyatidae \\
\hline 147 & $* *$ & Synaptura commersonii & Soleidae \\
\hline 148 & & Sea cucumber sp. C & Holothuroidea \\
\hline 149 & $*$ & Arius caelatus & Ariidae \\
\hline 150 & $*$ & Caridean sp. 3 & Palaemonidae \\
\hline 151 & $* *$ & Alepes melanoptera & Carangidae \\
\hline
\end{tabular}

Shortnosed tripodfish $\quad 15$

$\begin{array}{llll}\text { Crucifix crab } & 15 & 110 & 19\end{array}$

$\begin{array}{llll}\text { Spider crab } & 14 & 20 & 13\end{array}$

$\begin{array}{llll}\text { Robber mantis shrimp } & 14 & 46 & 41\end{array}$

$\begin{array}{llll}\text { Green rough-backed blowfish } & 14 & 48 & 28\end{array}$

Hair-fin anchovy $\quad 13 \quad 92 \quad 9$

$\begin{array}{llll}\text { Soldier croaker } & 13 & 56 & 25\end{array}$

$\begin{array}{llll}\text { Frog shell } & 12 & 29 & 13\end{array}$

Xanthid crab $\quad 1 2 \longdiv { 5 4 } \quad 1 6$

$\begin{array}{llll}\text { Mantis shrimp } & 12 & 90 & 9\end{array}$

$\begin{array}{llll}\text { Otomebora mullet } & 12 & 58 & 19\end{array}$

$\begin{array}{llll}\text { Zebra shark } & 11 & 37 & 25\end{array}$

Viviparous half-beak $\quad 11 \quad 15 \quad 16$

$\begin{array}{lll}\text { Common squillid mantis shrimp } & 10 & 96\end{array}$

$\begin{array}{llll}\text { Sea cucumber } & 10 & 25 & 16\end{array}$

Worm $10 \quad 10 \quad 50 \quad 9$

$\begin{array}{llll}\text { Swimming crab } & 10 & 11\end{array}$

$\begin{array}{llll}\text { Tiger-toothed croaker } & 9 & 147 & 13\end{array}$

$\begin{array}{llll}\text { Sea cucumber } & 9 & 14 & 13\end{array}$

$\begin{array}{llll}\text { Jellyfishes } & 8 & 7819 & 3\end{array}$

$\begin{array}{llll}\text { Selar } & 8 & 7 & 3\end{array}$

Walking goby

Sea cucumber

Veined catfish

Green mud crab

Spider crab

Caridean prawn

Giant tiger prawn

Hermit crab

Indian hump head

Sea cucumber

Soldier cat-fish

Leaf porter crab

Blue-spotted ribbon-tail ray

Sharp-rostrum prawn

Slipper limpets

Sea cucumber

Sea cucumber

Bearded croaker

Hairy crab

Caridean prawn

Sea cucumber

Slender moray

Gaimard's half-beak

Goblin fish

Rockshell

Kampen's ilisha

Pickhandle barracuda

Blue-spotted stingray

Commerson's sole

Sea cucumber

Engraved catfish

Caridean prawn

Blackfin crevalle 
Lutjanidae

Penaeidae

Mullidae

Pectinidae

Gobiidae

Lutjanidae

Muglidae

Ophichthyidae

Paralichthyidae

Elopidae

Eleotridae

Belonidae

Sciaenidae

Anabantidae

Plotosidae

Thalassinidae

Polychaeta

Polychaeta

Holothuroidea

Polychaeta

Dasyatidae

Atherinidae

Paguridae

Polychaeta

Platycephalidae

Sciaenidae

Dasyatidae

Sciaenidae

Serranidae

Stomatopoda
Snapper

Indian white prawn

Yellow goatfish

Scallop

Longjaw goby

Mangrove red snapper

Mullet

Wrinkled-skin snake eel

Largetooth flounder

Tenpounder

Gudgeon

Round-tail alligator gar

Karut croaker

Climbing perch

Striped eel catfish

Mud shrimp

Polychaete worms

Polychaete worms

Sea cucumber

Polychaete worms

Banded whiptail stingray

Tropical silverside

Hermit-crabs

Polychaete worms

Indian flathead

Panna croaker

Black-edged stingray

Croaker juveniles

Grouper juveniles

Mantis shrimps

\begin{tabular}{|c|c|}
\hline 2 & 645 \\
\hline 2 & 16 \\
\hline 2 & 4 \\
\hline 2 & 1 \\
\hline 2 & 19 \\
\hline 2 & 6 \\
\hline 2 & 3 \\
\hline 2 & 260 \\
\hline 2 & 34 \\
\hline 2 & 17 \\
\hline 2 & 4 \\
\hline 2 & 1 \\
\hline 2 & 47 \\
\hline 2 & 108 \\
\hline 2 & 83 \\
\hline 2 & 2 \\
\hline 1 & 3 \\
\hline 1 & 1 \\
\hline 1 & 3 \\
\hline 1 & 0 \\
\hline 1 & 46 \\
\hline 1 & 1 \\
\hline 1 & 0 \\
\hline 1 & 2 \\
\hline 1 & 1 \\
\hline 1 & 39 \\
\hline 1 & 33 \\
\hline 1172 & 2356 \\
\hline 99 & 82 \\
\hline 215 & 30 \\
\hline \multirow[t]{4}{*}{25231} & 40165 \\
\hline & 1102 \\
\hline & 18964 \\
\hline & 2574 \\
\hline
\end{tabular}

TOTAL:

** commercially-exploited

* low commercial value but consumed

\# unidentified due to highly damaged condition 